\title{
Ultrastructural Localization of Full-Length trkB Immunoreactivity in Rat Hippocampus Suggests Multiple Roles in Modulating Activity- Dependent Synaptic Plasticity
}

\author{
C. T. Drake, ${ }^{1}$ T. A. Milner, ${ }^{1}$ and S. L. Patterson ${ }^{2}$ \\ ${ }^{1}$ Division of Neurobiology, Department of Neurology and Neuroscience, Weill Medical College, Cornell University, New \\ York, New York 10021, and ${ }^{2}$ Center for Neurobiology and Behavior, Columbia University, College of Physicians and \\ Surgeons, New York, New York 10032
}

Neurotrophins acting at the trkB receptor have been shown to be important modulators of activity-dependent plasticity in the hippocampus, but the mechanisms underlying these effects are not yet well understood. To identify the cellular and subcellular targets of trkB ligands in the adult rat hippocampal formation, full-length trkB receptor immunoreactivity (trkB-IR) was localized using electron microscopy. trkB-IR was present in the glutamatergic pyramidal and granule cells. Labeling in these neurons appeared as discrete clusters and was primarily in axons, excitatory-type axon terminals, and dendritic spines and to a lesser extent in somata and dendritic shafts. trkB-IR was commonly found on the plasma membrane of dendritic spines, whereas in other subcellular regions trkB-IR was often intracellular. Labeling was strikingly dense within axon initial segments, suggesting extensive receptor trafficking. trkB-IR was not confined to pyramidal and granule cells. Dense trkB-IR was found in occasional interneuron axon initial segments, some axon terminals forming inhibitory-type synapses onto somata and

Neurotrophins have historically been ascribed roles in the survival, development, and maintenance of neurons. However, many of their recently documented actions-rapid modulation of firing rates, ion channels, and neurotransmitter synthesis and release, as well as slower modifications of cytoarchitecture-are consistent with a more dynamic role in modulating neural connections (for review, see Lo, 1995; Thoenen, 1995; Lu and Figurov, 1997). Several lines of evidence suggest that neurotrophins, particularly those acting at the trkB neurotrophin receptor, modulate activitydependent plasticity in hippocampal formation. First, trkB receptor as well as its ligands brain-derived neurotrophic factor (BDNF), neurotrophin-4/5 (NT-4/5), and the lower-affinity NT-3 (Klein et al., 1990; Lamballe et al., 1991; Gall and Lauterborn, 1992; Timmusk et al., 1993; Friedman et al., 1998) are found in hippocampal neurons. Second, expression of trkB receptor and its ligands is modulated by neuronal activity, including experimen-

Received March 1, 1999; revised June 10, 1999; accepted June 15, 1999.

This work was supported by an Aaron Diamond postdoctoral fellowship (C.T.D.), National Institutes of Health Grants DA08259 and MH42834 (T.A.M.) and GM08464, and a grant from the National Alliance for Research on Schizophrenia and Depression (S.L.P.). We thank Drs. Sue Aicher, Adena Svingos, Danny Winder, Joseph Pierce, and Karen Dougherty for helpful comments and Sabrina Prince and Joy Hornung for technical assistance.

Correspondence should be addressed to Dr. Carrie Drake, Division of Neurobiology, Cornell University Medical College, 411 East 69th Street, Room KB-410, New York, New York 10021.

Copyright (C) 1999 Society for Neuroscience 0270-6474/99/198009-18\$05.00/0 dendritic shafts, and excitatory-type terminals likely to originate extrahippocampally. This suggests that trkB is contained in some GABAergic interneurons, neuromodulatory (e.g., cholinergic, dopaminergic, and noradrenergic) afferents, and/or glutamatergic afferents. These data indicate that full-length trkB receptor activation may modulate glutamatergic pathways of the trisynaptic circuit both presynaptically at axon terminals and initial segments and postsynaptically at dendritic spines and shafts. Signaling via catalytic trkB may also presynaptically affect inhibitory and modulatory neurons. A pan-trkB antibody labeled the same neuronal populations as the full-lengthspecific trkB antiserum, but the labels differed in density at various subcellular sites. These findings provide an ultrastructural foundation for further examining the mechanisms through which neurotrophins acting at trkB receptors contribute to synaptic plasticity.

Key words: neurotrophin; trkB; ultrastructure; electron microscopy; plasticity; BDNF

tally induced seizures (Gall and Lauterborn, 1992; Merlio et al., 1993) and long-term potentiation (LTP) (Patterson et al., 1992; Castren et al., 1993; Bramham et al., 1996; Dragunow et al., 1997). Third, activity of hippocampal neurons can be modulated by alterations in neurotrophin levels. Exogenous BDNF induces rapid enhancement of synaptic transmission in hippocampal dissociated cell cultures (Leßmann et al., 1994; Levine et al., 1995), in slices (Kang and Schuman, 1995, 1996), and in vivo (Messaoudi et al., 1998). LTP is greatly reduced in BDNF knock-out mice but is rescued by restoring BDNF (Korte et al., 1995, 1996; Patterson et al., 1996). Similarly, pretreatment of hippocampal slices with a trkB-IgG fusion protein to scavenge free BDNF greatly attenuates LTP (Figurov et al., 1996).

Several lines of evidence suggest that neurotrophin actions are likely to be varied and complex. Both retrograde (Bothwell, 1995; von Bartheld et al., 1996b) and anterograde (von Bartheld et al., 1996a; Altar and DiStefano, 1998; Fawcett et al., 1998) transport of neurotrophins have been demonstrated in the CNS. Hippocampal pyramidal and dentate granule cells express trkB and BDNF, suggesting possible autocrine and paracrine actions (Kokaia et al., 1993). Electrophysiological studies suggest that trkB ligands enhance hippocampal synaptic transmission by presynaptic actions on axon terminals (Leßmann et al., 1994; Kang and Schuman, 1995; Levine et al., 1995; Scharfman, 1997; Messaoudi et al., 1998). However, there are also indications that neurotrophin-mediated enhancement involves postsynaptic trkB 
receptors on somata and/or dendrites (Levine et al., 1995; Tanaka et al., 1997). Adding to the complexity, alternative splicing of trkB mRNA produces at least three different trkB receptor isoforms with different signaling capabilities: the full-length "catalytic" receptor and two truncated forms lacking the intracellular tyrosine kinase. These forms are differentially expressed during development and after neuronal activity and have been postulated to have distinct functions (Bothwell, 1995).

Two recent survey studies (Fryer et al., 1996; Yan et al., 1997) used light-microscopic immunocytochemistry to examine the distribution of trkB in the rat forebrain. The antibody used almost exclusively in both studies was raised against the extracellular portion of trkB common to both full-length and truncated forms. Because the full-length and truncated forms of trkB are likely to carry out different functions, a precise knowledge of the distributions of the different isoforms is necessary to fully understand the action of neurotrophins in hippocampal formation. For example, the current controversy over whether the effects of trkB ligands on synaptic plasticity are presynaptic or postsynaptic can be addressed with ultrastructural localization of trkB receptors. Thus, in the present study we have used a combination of light and electron microscopy to determine the broad cellular distribution and subcellular location of immunoreactivity specific for the full-length trkB receptor in the hippocampus and dentate gyrus.

\section{MATERIALS AND METHODS}

Antisera. A polyclonal rabbit antiserum against trkB was generously supplied by Dr. David Kaplan (Montreal Neurological Institute, McGill University, Montreal, Quebec, Canada). This antiserum, referred to here as "trkB" and previously called "trkB-in," was raised against a synthetic peptide (HISNGSNTPSSSEGGPDAVI) corresponding to amino acids 482-501 in the predicted cytoplasmic domain of full-length trkB, which the truncated forms lack (for review, see Bothwell, 1995). This antiserum was previously shown to recognize the full-length trkB receptor but not the full-length trkA or trkC receptors on Western blots of Sf9 insect cells expressing these receptors (Fryer et al., 1996). In addition, the trkB antiserum recognizes the full-length trkB receptor but not the truncated trkB receptor on blots of wheat germ lectin precipitates of adult hippocampal formation (Fryer et al., 1996).

An affinity-purified polyclonal trkB antibody ("trkB ${ }_{23-36}$ "; generously provided by Dr. Stuart Feinstein, Neuroscience Research Institute, University of California, Santa Barbara, CA) was also used for comparative purposes. This antibody was generated in rabbit against a synthetic peptide from the extracellular portion of the trkB receptor (amino acids 23-36). It was shown to recognize both full-length and truncated trkB receptors on Western blots of adult rat hippocampal formation and specificity in fixed tissue immunocytochemistry was demonstrated by preadsorbing the antiserum with trkB-expressing Sf9 insect cells (Fryer et al., 1996).

Immunocytochemistry. Ten adult male Sprague Dawley rats (Hilltop Lab Animals, Scottdale, PA), weighing 355-385 gm ( $\sim 65-75 \mathrm{~d}$ old) were used. Rats were injected with sodium diethyl dithiocarbamate (DEDTC) $(0.5 \mathrm{mg} / \mathrm{kg}$, i.p.) to eliminate artifactual immunogold labeling of endogenous zinc stores (Veznedaroglu and Milner, 1992), deeply anesthetized with sodium pentobarbital, and perfused sequentially with (1) $10-20 \mathrm{ml}$ of normal saline containing $1000 \mathrm{U} / \mathrm{ml}$ heparin, (2) $3.75 \%$ acrolein (Polysciences, Warrington, PA) and 2\% paraformaldehyde in $0.1 \mathrm{M}$ phosphate buffer (PB; pH 7.4), and (3) $2 \%$ paraformaldehyde in PB. The brains were removed from the skull, cut into 5-6 $\mathrm{mm}$ coronal blocks, and post-fixed in the last fixative for $30 \mathrm{~min}$. Coronal sections (40 $\mu \mathrm{m}$ thick) were cut through the hippocampal formation on a vibrating microtome (Vibratome) and collected in PB. Free-floating sections were selected from the midseptotemporal portion and pretreated with $1 \%$ sodium borohydride in PB (Eldred et al., 1983).

Most sections were processed for immunocytochemistry using a modification of the avidin-biotin-peroxidase complex technique (Hsu et al., 1981) as previously described (Drake et al., 1996). To enhance reagent penetration, tissue processed for light microscopy (LM) contained $0.25 \%$
Triton $\mathrm{X}-100$ in the primary antibody diluent, whereas most sections processed for electron microscopy (EM) were treated with a modification of the "freeze-thaw" technique (Drake et al., 1996). Tissue was incubated sequentially in (1) 1:2000-1:3000 dilution of trkB antiserum [diluent: $0.1 \mathrm{M}$ Tris-saline buffer (TS, $\mathrm{pH} 7.6$ ) and $0.1 \%$ bovine serum albumin (BSA)] for $36-40 \mathrm{hr}$ at $4^{\circ} \mathrm{C},(2)$ biotinylated goat anti-rabbit $\mathrm{IgG}$ (Vector Laboratories, Burlingame, CA) diluted 1:400 in TS and 0.1\% BSA for $30 \mathrm{~min}$ at room temperature, and (3) avidin-biotin-peroxidase complex (ABC) (Vectastain Elite kit; Vector) at twice the recommended dilution in TS for $30 \mathrm{~min}$ at room temperature. Tissue was rinsed in TS between incubations. Immunolabeling was visualized by incubating sections in PB containing 3,3'-diaminobenzidine $(0.22 \%)$ and hydrogen peroxide $(0.00003 \%)$.

Some sections were processed using the immunogold-silver method (Chan et al., 1990). Although less sensitive than immunoperoxidase, the gold-labeling technique allows greater precision in identifying the subcellular distribution of immunoreactive sites. Sections were pretreated with sodium borohydride, rinsed, and freeze-thawed twice to optimize immunogold labeling. Sections were incubated in trkB antiserum (diluted 1:300 in TS with $0.1 \% \mathrm{BSA}$ ) for $36-40 \mathrm{hr}$ at $4^{\circ} \mathrm{C}$, rinsed in TS followed by $0.01 \mathrm{M}$ PBS, pH 7.4, and then incubated in PBS containing $0.1 \%$ gelatin and $0.8 \%$ BSA for $30 \mathrm{~min}$. Next, sections were incubated for $2 \mathrm{hr}$ in goat anti-rabbit IgG conjugated to $1 \mathrm{~nm}$ gold particles (Amersham, Arlington Heights, IL) diluted 1:50 in PBS, gelatin, and BSA. The sections were rinsed in PBS, incubated 10 min in $2 \%$ glutaraldehyde, transferred to $0.2 \mathrm{M}$ sodium citrate, $\mathrm{pH} 7.4$, and intensified in a silver solution (IntenSE kit; Amersham) for 6-8 min.

Two types of control experiments were conducted in parallel with normal immunolabeling. First, to examine whether labeling was nonspecific due to secondary antibody or other processing steps, the trkB antiserum was omitted from the primary antibody incubation. Second, although the trkB antiserum was previously shown to be specific for the full-length trkB receptor in Western blots (Allendoerfer et al., 1994; Fryer et al., 1996), specificity in acrolein/paraformaldehyde-fixed tissue was demonstrated with adsorption controls. TrkB antiserum was incubated with $1 \mathrm{~mm}$ antigenic peptide overnight at $4^{\circ} \mathrm{C}$ and then substituted for the untreated primary antiserum on some sections.

Final preparation and analysis. For LM, immunolabeled sections were mounted onto gelatin-coated glass slides, dried, dehydrated through ethanols and xylenes, and coverslipped in DPX mounting medium (Aldrich, Milwaukee, WI). The hippocampal formation was examined and photographed using a Nikon Microphot microscope equipped with bright-field and differential interference contrast optics.

For EM, labeled sections were fixed in $2 \%$ osmium tetroxide in $\mathrm{PB}$ for $1 \mathrm{hr}$, rinsed in $\mathrm{PB}$, dehydrated through a series of ethanols and propylene oxide, and flat-embedded in EMBed between two sheets of Aclar plastic. Immunolabeled regions of the dentate gyrus and the CA1 region of hippocampus were glued onto Epon blocks, and ultrathin $(\sim 60 \mathrm{~nm})$ sections were cut on an ultramicrotome and collected on copper grids. Sections were counterstained with uranyl acetate and lead citrate (Reynolds, 1963) and then examined and photographed on a Philips CM10 electron microscope (Mahwah, NJ).

Qualitative EM analysis of immunoperoxidase- and immunogoldlabeled tissue was conducted on tissue from eight animals, using standardized definitions of somata, dendrites, axons, axon terminals, or glia (Peters et al., 1991). Synapses were identified based on the presence of a clear synaptic specialization, a widened synaptic cleft with parallel membranes, and three or more synaptic vesicles presynaptically and were classified as asymmetric (excitatory-type) or symmetric (inhibitory-type). Some terminals possessed distinctive features (shape, size, vesicle content, and synaptic morphology) that allowed their categorization as "excitatory-type" or "inhibitory type," based on previous descriptions of glutamatergic and GABAergic terminals, respectively (Bramham et al., 1990; Peters et al., 1991; Freund and Buzsaki, 1996). It should be noted that terminals containing acetylcholine, serotonin, or catecholamines form a small proportion of the asymmetric synapses and symmetric synapses in hippocampal formation (reviewed by Freund and Buzsaki, 1996), and the postsynaptic effects of these neurotransmitters are variously excitatory or inhibitory, depending on the available receptor subtypes (Andrade et al., 1986; Marchi et al., 1989; Alkondon et al., 1997; McMahon and Kauer, 1997).

Quantification of the EM distribution of trkB-immunoperoxidaselabeled profiles was performed in the CA1 region of the hippocampus and the dentate gyrus. Two $40 \mu \mathrm{m}$ tissue sections from each of three animals were examined for each region. From each $40 \mu \mathrm{m}$ section, 
ultrathin sections were prepared for EM examination, and $55 \times 55 \mu \mathrm{m}$ fields were selected from each CA1 lamina [alveus, stratum (st.) oriens, st. pyramidale, st. radiatum, and st. lacunosum-moleculare] or each dentate gyrus lamina (st. moleculare, st. granulosum, and hilus). Criteria for selection included good morphological preservation, the presence of immunolabeling, and proximity to the Epon-tissue interface (to minimize undercounting caused by limited reagent penetration; Pickel et al., 1993). All immunolabeled profiles within each selected field were photographed. Labeled profiles were counted and scored by type, and synapses were counted and classified as symmetric or asymmetric. Profiles that lacked identifying characteristics were counted and classified as "unknown." All profiles were counted before sorting by laminar location and by animal. Within each lamina, the mean values for each profile type per $55 \times 55 \mu \mathrm{m}$ field were calculated for each animal. A Mann-Whitney rank-sum test (Sigmastat software) was used to evaluate differences between presynaptic and postsynaptic profiles in each lamina.

\section{RESULTS}

\section{Light microscopic immunoreactivity for full-length trkB in hippocampus and dentate gyrus}

To determine the extent of catalytic trkB-IR in the hippocampal formation and to provide LM images for comparison with those from earlier studies, we used light microscopy to examine sections labeled with trkB-immunoperoxidase. Labeling was present in both CA1 and CA3 regions of the hippocampus proper and in the dentate gyrus. TrkB-IR was present predominantly in short smooth processes extending from somata and to a lesser extent was in somata, thin beaded fibers, and scattered small punctate structures (Fig. $1 B-E$ ).

The morphology and orientation of the short $(\leq 30 \mu \mathrm{m})$, smooth trkB-labeled processes suggested that they might be axon initial segments of pyramidal cells and granule cells (i.e., principal neurons). In CA1 and CA3 regions (Fig. $1 B, C$ ), the short labeled processes were in st. pyramidale and the adjacent portion of st. oriens but not st. radiatum. In the dentate gyrus (Fig. 1D) these processes were in st. granulosum and hilus.

trkB-IR was present in the somata of most neurons in st. pyramidale, and st. granulosum (Fig. $1 B-D$ ). In addition, trkB-IR was present in somata and putative axon initial segments of a few neurons in all hippocampal and dentate gyrus laminae except st. moleculare of the dentate gyrus (Fig. $1 B-D$ ). The size and location of most of these neurons suggested that they might be inhibitory GABA- and/or GAD-containing interneurons (Freund and Buzsaki, 1996). However, some of the large trkB-labeled neurons in the hilus of the dentate gyrus were similar in size and location to both excitatory glutamate-containing mossy cells (Ribak et al., 1985; Buckmaster et al., 1993; Soriano and Frotscher, 1994) and large inhibitory interneurons of that region (Amaral, 1978; Freund and Buzsaki, 1996).

The small punctate structures with trkB-IR, some of which were clearly connected by fine fibers (Fig. 1C), corresponded to the light microscopic appearance of beaded axons and axon terminals. These structures were present in all subfields of hippocampus proper and the dentate gyrus (Fig. $1 B-D$ ). They were concentrated in the infragranular hilus of the dentate gyrus (Fig. $1 D$ ) and were more dispersed in other laminae and fields (Fig. $1 B-D)$.

\section{Specificity of full-length trkB labeling}

Omission of the primary antiserum resulted in a complete absence of labeling. Similarly, labeling was completely abolished in adsorption controls examined using light microscopy (Fig. 1G). When adsorption controls were examined using electron microscopy, some residual labeling was seen in endosomes and in glia.
Reaction product was also present in a very few morphologically compromised spines, axons, and terminals.

In addition to an extensive light microscopic characterization of the labeling pattern obtained with another antiserum, Fryer et al. (1996) also provided a brief description of the labeling pattern obtained with the full-length-specific trkB antiserum previously denoted trkB-in. In the micrograph shown by Fryer et al. (1996), the full-length trkB antiserum strongly labeled apical dendrites in hippocampus. Because we did not observe this pattern using the same antiserum, we undertook an additional series of control experiments, varying our antiserum concentration and tissue fixative to more closely resemble the labeling conditions used in the earlier study (Fryer et al., 1996). Both acrolein/ paraformaldehyde-fixed sections and $4 \%$ paraformaldehyde-fixed sections were tested, and trkB antiserum was serially diluted 1:200-1:2000 with both fixations. With all conditions tested, we obtained our original labeling pattern, although darker labeling and a diffuse background were present with more concentrated trkB antiserum and weaker tissue fixation (Fig. $1 E$ ). These results indicate that the conditions subsequently used to process tissue for EM analysis were optimal and provided a complete representation of the specific labeling pattern for this antiserum. The reason for the discrepancy with the previous description may be attributable to the differences in processing technique (e.g., the use of frozen sections and peroxidase-antiperoxidase in the earlier study vs vibratome sections and $\mathrm{ABC}$ in the present study).

\section{Light microscopic comparison of labeling with two trkB antisera}

The labeling pattern obtained with the antiserum against fulllength trkB was compared with that obtained using a different trkB antiserum ( $\left.\operatorname{trkB}_{23-36}\right)$, which recognizes both full-length and truncated forms of the trkB receptor under the denaturing conditions of Western blots (Fryer et al., 1996). Using LM, the trkB $\mathrm{B}_{23-36}$ antiserum was previously shown to heavily label pyramidal cell apical dendritic shafts and was specific, as determined by an immunocytochemical adsorption control (Fryer et al., 1996; Yan et al., 1997). Using either acrolein/paraformaldehyde or $4 \%$ paraformaldehyde fixation and diluting the antibody 1:200-1: 1000 , we observed the same labeling pattern with $\operatorname{trkB}_{23-36}$ (Fig. $1 F)$ as Fryer and colleagues (1996). There are several possible reasons why the labeling pattern of $\operatorname{trkB}_{23-36}$ did not completely overlap the full-length-specific trkB labeling pattern. Contributing factors may have included impaired recognition of the fulllength trkB protein by the $\mathrm{trkB}_{23-36}$ antibody because of different extracellular conformation or modifications of the extracellular domain (Williams et al., 1994) or greater detection of the much more abundant truncated form of trkB by $\operatorname{trkB}_{23-36}$ antibody in fixed tissue. In support of the latter possibility, Fryer et al. (1996) reported that a higher concentration of $\operatorname{trkB}_{23-36}$ was required for fixed tissue immunocytochemistry than for Western blots, an indication that fixation may have compromised tissue immunoreactivity.

\section{By electron microscopy, trkB-IR is intense in axon initial segments of pyramidal and granule neurons and less intense in axons}

Because trkB-mediated effects on synaptic plasticity have been demonstrated in the CA1 region of hippocampus and the dentate gyrus (Kang and Schuman, 1995; Korte et al., 1995; Figurov et al., 1996; Patterson et al., 1996; Scharfman, 1997; Messaoudi et al., 1998), we focused our EM analysis on these regions. As was observed with LM, the most dramatic labeling for full-length 

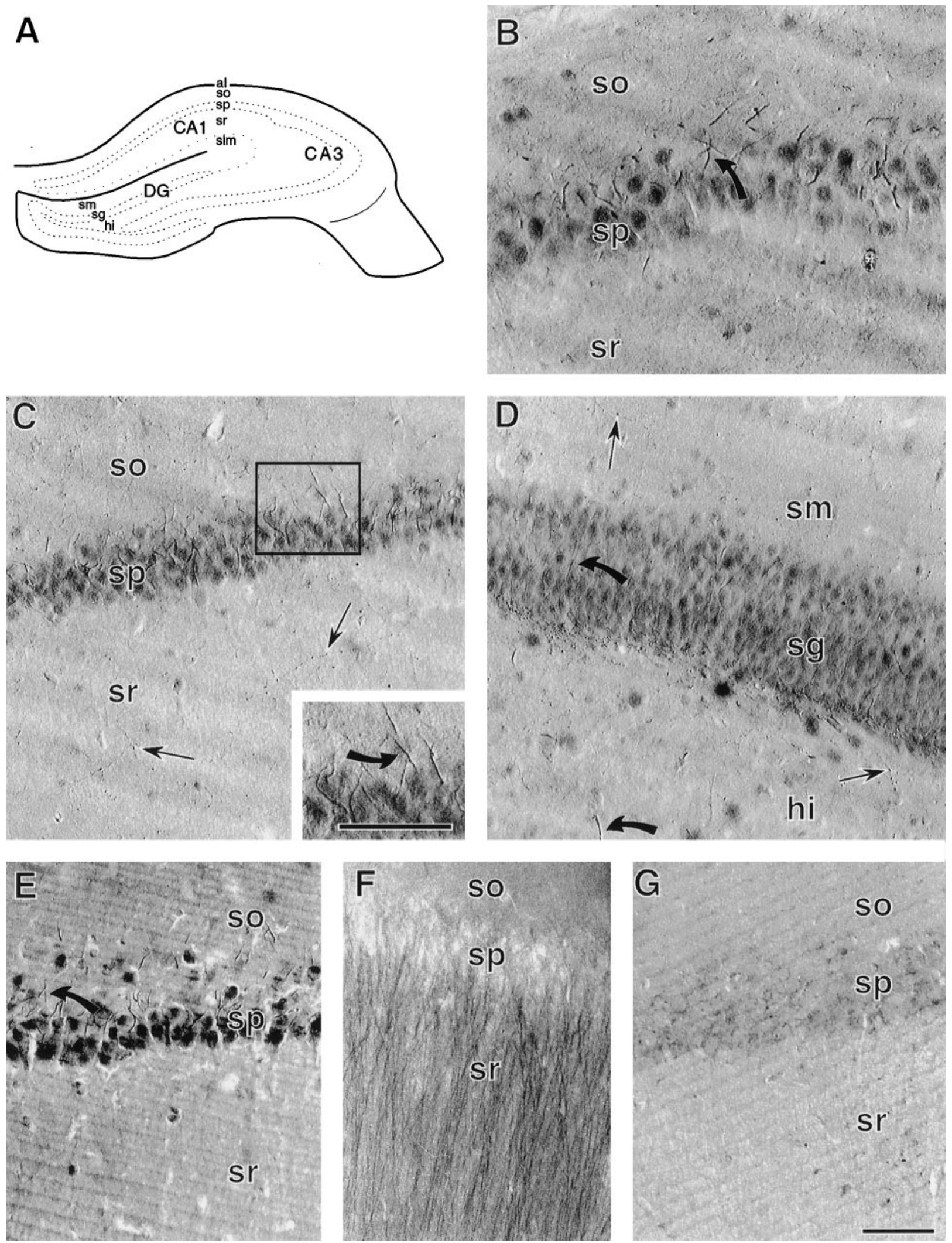

Figure 1. Light microscopy and specificity of trkB-IR. A, Schematic of a coronal section through the hippocampal formation (adapted from Swanson, 1995). al, Alveus; $h i$, hilus; $s g$, st. granulosum; $s l m$, st. lacunosum-moleculare; $s o$, st. oriens; $s p$, st. pyramidale; $s m$, st. moleculare; $s r$, st. radiatum. $B$, In the CA3 region of hippocampus, trkB-IR is present in neuronal somata and smooth processes (example indicated by the curved arrow) extending from neurons in st. pyramidale, and in small punctate structures in st. radiatum and st. oriens. $C$, In the CA1 region of hippocampus, trkB-IR is present in neuronal somata and in processes extending into st. oriens (inset, curved arrow), as well as in scattered fine beaded processes (straight arrows) in st. radiatum. $D$, In dentate gyrus, st. granulosum and the hilus contain darkly labeled somata and smooth, tapering processes (curved arrows) extending from somata. Fine punctate processes (straight arrows) are present in the hilus and st. moleculare. E, In the CA1 region, different (Figure legend continues) 

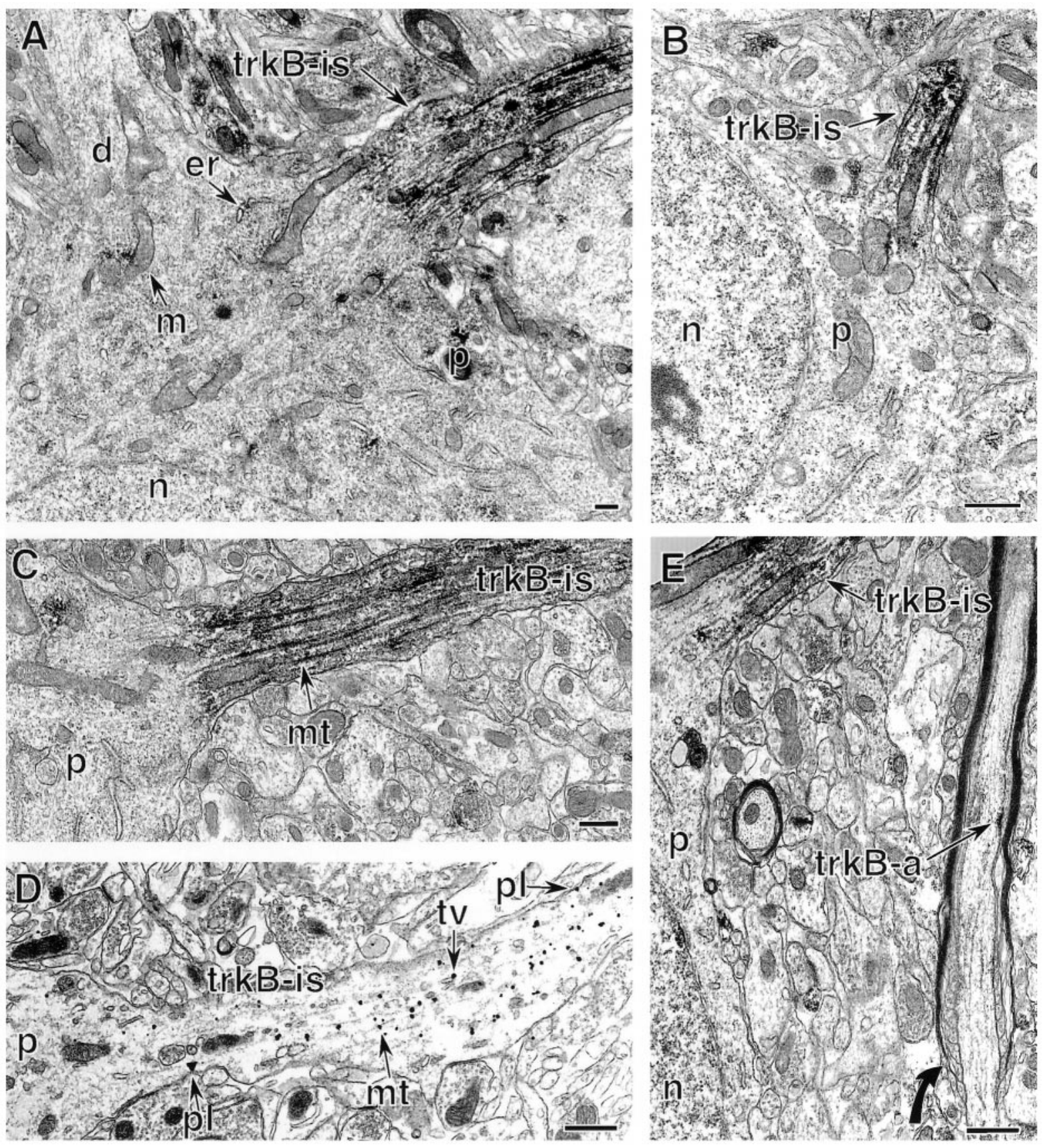

Figure 2. Dense trkB-IR is present in the axon initial segments of principal cells. $A$, A labeled pyramidal cell axon initial segment (trkB-is) contains intense trkB-IR. The somatic perikaryon $(p)$ contains clusters of labeling affiliated with endoplasmic reticulum $(e r)$ and mitochondria $(m)$. The nucleus $(n)$ and a primary dendrite $(d)$ lack labeling. $B$, In the dentate gyrus, intense trkB-IR is in an axon initial segment (trkB-is) of a granule cell. The somatic perikaryon $(p)$ and nucleus $(n)$ are unlabeled. $C$, Higher magnification of a labeled pyramidal cell axon initial segment (trkB-is) shows peroxidase labeling associated with the plasmalemma and microtubule fascicles $(m t)$. $D$, TrkB-immunogold labeling is affiliated with bundled microtubules $(m t)$, membranes of tubulovesicular organelles $(t v)$, and occasionally the plasma membrane $(p l)$ of a pyramidal cell axon initial segment $(t r k B$-is). E, A pyramidal cell axon initial segment (trkB-is) contains dense, abundant trkB labeling. In contrast, a nearby axon (trkB- $a$ ), which is at the initiation of myelination (curved arrow) and likely originates from a pyramidal cell, contains a small patch of labeling along the plasma membrane. Scale bars, $0.5 \mu \mathrm{m}$.

\section{$\leftarrow$}

processing conditions (4\% paraformaldehyde fixation and trkB antiserum diluted 1:200) result in trkB labeling that is darker with increased diff use background but is otherwise like that seen with acrolein and paraformaldehyde fixation and trkB antiserum diluted 1:2000 (compare with $C$ ). $F$, Pyramidal cell apical dendrites are prominently labeled in the CA1 region of acrolein- and paraformaldehyde-fixed tissue incubated in an antibody $\left(\operatorname{trkB}_{23-36}\right.$, diluted 1:500) raised against a peptide common to both the full-length and truncated trkB receptors. $G$, The CA1 region of an adsorption control section contains virtually no trkB labeling (compare with $C$ ). Scale bars, $50 \mu \mathrm{m}$. 


\begin{tabular}{|c|c|c|c|c|}
\hline & $\begin{array}{l}\text { Forming asymmetric } \\
\text { synapses }\end{array}$ & $\begin{array}{l}\text { Forming symmetric } \\
\text { synapses }\end{array}$ & $\begin{array}{l}\text { Total forming } \\
\text { synapses }\end{array}$ & $\begin{array}{l}\text { Total number } \\
\text { of terminals }\end{array}$ \\
\hline \multicolumn{5}{|l|}{ CA1 region } \\
\hline Alveus & 1 & 4 & 5 & 25 \\
\hline St. oriens & 23 & 5 & 28 & 78 \\
\hline St. pyramidale & 0 & 10 & 10 & 25 \\
\hline St. radiatum & 13 & 1 & 14 & 54 \\
\hline St. lacun-molec. & 5 & 5 & 10 & 30 \\
\hline Total & 52 & 15 & 67 & 212 \\
\hline \multicolumn{5}{|l|}{ Dentate gyrus } \\
\hline Hilus & 14 & 2 & 16 & 70 \\
\hline St. granulosum & 3 & 1 & 4 & 25 \\
\hline Inner St. moleculare & 10 & 1 & 11 & 58 \\
\hline Total & 27 & 4 & 31 & 153 \\
\hline
\end{tabular}

trkB in the hippocampal formation was in axon initial segments of pyramidal and granule cells (Fig. 2). Labeled initial segments of pyramidal cells (Fig. 2A,C-E) were approximately the same diameter and orientation as proximal basal dendrites extending into st. oriens (Fig. 2A), whereas the initial segments of granule cells were somewhat smaller and extended into the hilus, in the opposite direction from the dendrites (Fig. $2 B$ ). In all cases, axon initial segments could be distinguished from dendrites by the presence of an "undercoating" along the plasma membrane, microtubules bundled into fascicles, and numerous mitochondria and tubulovesicular organelles (irregularly shaped organelles consisting of an outer membrane and a clear lumen, generally of minimum diameter $>80 \mathrm{~nm}$ ).

trkB-labeled axon initial segments contained a dense accumulation of peroxidase reaction product along the microtubules and less prominent labeling along the plasma membrane, tubulovesicular organelles resembling the membrane precursors of small synaptic vesicles (Mundigl and De, 1994), and occasional mitochondria (Fig. $2 A-C, E$ ). This localization was confirmed in sections labeled with immunogold (Fig. 2D); silver-enhanced gold particles were associated primarily with microtubules, to a lesser extent with tubulovesicles and plasma membranes, and occasionally with mitochondria.

Beyond the axon initial segments, the pattern of trkB-IR was strikingly different. Labeled axons contained much sparser trkBIR, which was often clustered around small vesicles or at the plasma membrane (Fig. 2E). TrkB-labeling was present both in axons resembling those of pyramidal cells (Fig. $2 E$ ) and in axons of unidentified origin. Finally, although trkB-labeled axons were observed relatively frequently (see Figs. 9, 10), many axons were not labeled, consistent with the discrete clusters of trkB-IR seen in the axons that did contain labeling.

\section{TrkB-IR is present in many types of excitatory-type axon terminals}

TrkB-IR was commonly observed in axon terminals. Some labeled terminals $(20 \%$ in dentate gyrus and $32 \%$ in the CA1 region; Table 1) formed synapses in the plane of section examined and thus could be identified as excitatory-type or inhibitory type, as defined in Materials and Methods. In the CA1 region, clusters of trkB-IR were observed relatively frequently in excitatory-type terminals in st. oriens and st. radiatum, whereas the alveus and st. pyramidale contained almost no labeled excitatory-type terminals (Table 1). Labeled excitatory-type terminals in st. oriens and st. radiatum formed synapses with CA1 pyramidal cell dendritic spines (Fig. 3A). This distribution and morphology resembled those of the Schaffer collaterals of CA3 pyramidal cells, which contribute a massive excitatory input to st. radiatum and st. oriens (Amaral and Witter, 1995). TrkB mRNA is present in CA3 pyramidal cells (Klein et al., 1990; Vazquez and Ebendal, 1991; Merlio et al., 1992), further supporting the idea that at least some of the trkB-labeled terminals are Schaffer collaterals.

St. lacunosum-moleculare of the CA1 region also contained excitatory-type trkB-labeled terminals, although less frequently than other laminae (Table 1). These terminals contained very dense trkB-IR and formed asymmetric synapses with both spines and shafts of dendrites (Fig. 3E,F). These densely labeled excitatory-type terminals were likely to arise from extrahippocampal sources, because st. lacunosum-moleculare is not innervated by hippocampal pyramidal cells (Amaral and Witter, 1995) but receives excitatory input from both cortical and subcortical areas such as the entorhinal cortex and the nucleus reuniens of the thalamus (Wouterlood et al., 1990; Desmond et al., 1994; Dolleman-Van der Weel et al., 1997).

In the hilus of the dentate gyrus, trkB labeling was occasionally (10 of 70 total hilar terminals; Table 1 ) observed in the distinctive glutamatergic "mossy fiber" terminals known to originate from granule cells (Fig. 3B). Some of the labeled mossy fiber terminals lacked synaptic specializations in the plane of section analyzed but could be identified by their large size ( $>2 \mu \mathrm{m}$ diameter), convoluted shape, and dense accumulations of small synaptic vesicles and dense-core vesicles (Blackstad, 1963; Claiborne et al., 1986). TrkB-IR also was detected relatively frequently (Table 1) in smaller, relatively densely labeled hilar terminals that innervated dendritic shafts and spines (Fig. 3D). These small excitatory-type labeled terminals are most likely en passant terminals of glutamatergic granule cells or hilar mossy cells (Amaral, 1978; Ribak et al., 1985; Claiborne et al., 1986; Buckmaster et al., 1996; Pierce et al., 1999) or subcortical afferents containing acetylcholine or catecholamines, which form some asymmetric synapses in the hilus (Clarke, 1985; Frotscher and Leranth, 1986; Milner and Bacon, 1989).

Sparsely labeled excitatory-type trkB-labeled terminals were 

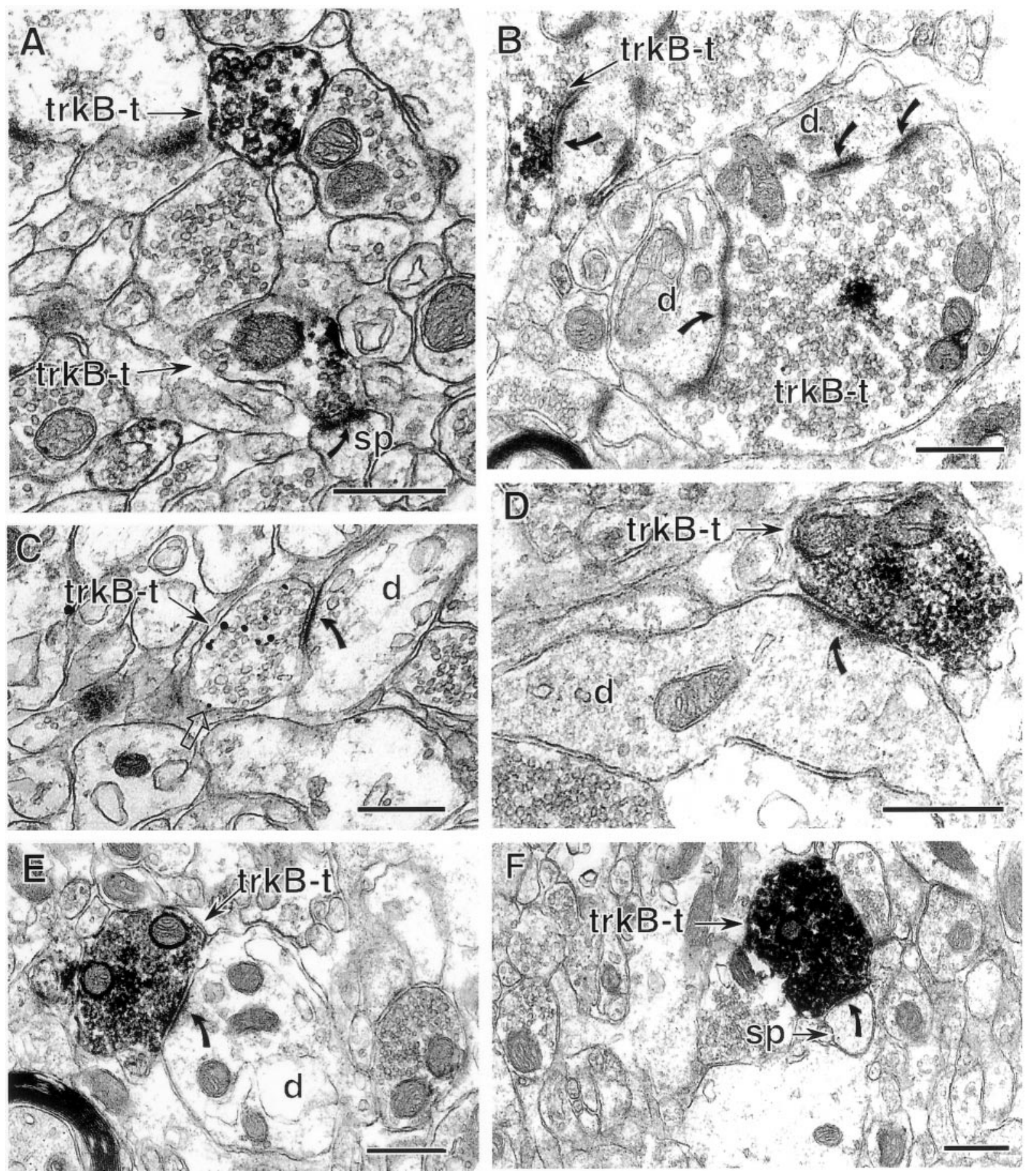

Figure 3. Excitatory-type axon terminals contain trkB-IR. $A$, Two terminals (trkB-t) in st. radiatum contain sparse trkB-immunogold labeling. The lower, sparsely labeled terminal forms an asymmetric (excitatory-type) synapse (curved arrow) with a dendritic spine ( $s p$ ). $B$, In the hilus of dentate gyrus, a cluster of trkB-IR is present in mossy fiber terminals $($ trkB- $t)$ identified by their large size and numerous asymmetric synapses $($ curved arrows) with dendrites $(d)$. $C$, A trkB-immunogold-labeled terminal $($ trkB- $t$ ) in st. oriens contains immunogold-silver particles affiliated with small synaptic vesicles and less commonly with the plasma membrane (open arrow). This terminal forms an asymmetric synapse (curved arrow) with an unlabeled dendrite ( $d$ ). $D$, A terminal (trkB-t) in the hilus contains dense trkB-IR and forms an asymmetric synapse (curved arrow) with the shaft of an unlabeled dendrite $(d)$. $E, F$, In st. lacunosum-moleculare, terminals with dense trkB-IR form asymmetric synapses (curved arrows) with an unlabeled dendritic shaft ( $E$ ) and an unlabeled dendritic spine $(F)$. Scale bars, $0.5 \mu \mathrm{m}$.

present in st. moleculare of the dentate gyrus, where they formed asymmetric synapses with dendritic spines. Labeled terminals were quite uncommon in the outer two-thirds of this lamina but were relatively frequent in the inner portion (Table 1). In contrast, only very few trkB-labeled terminals forming asymmetric synapses were detected in st. granulosum (Table 1). These terminals also contained sparse trkB-IR and contacted the somata of granule cells and large dendrites, some of which clearly originated from granule cells. Possible sources of the labeled terminals in st. granulosum and inner st. moleculare include hilar mossy cells, 


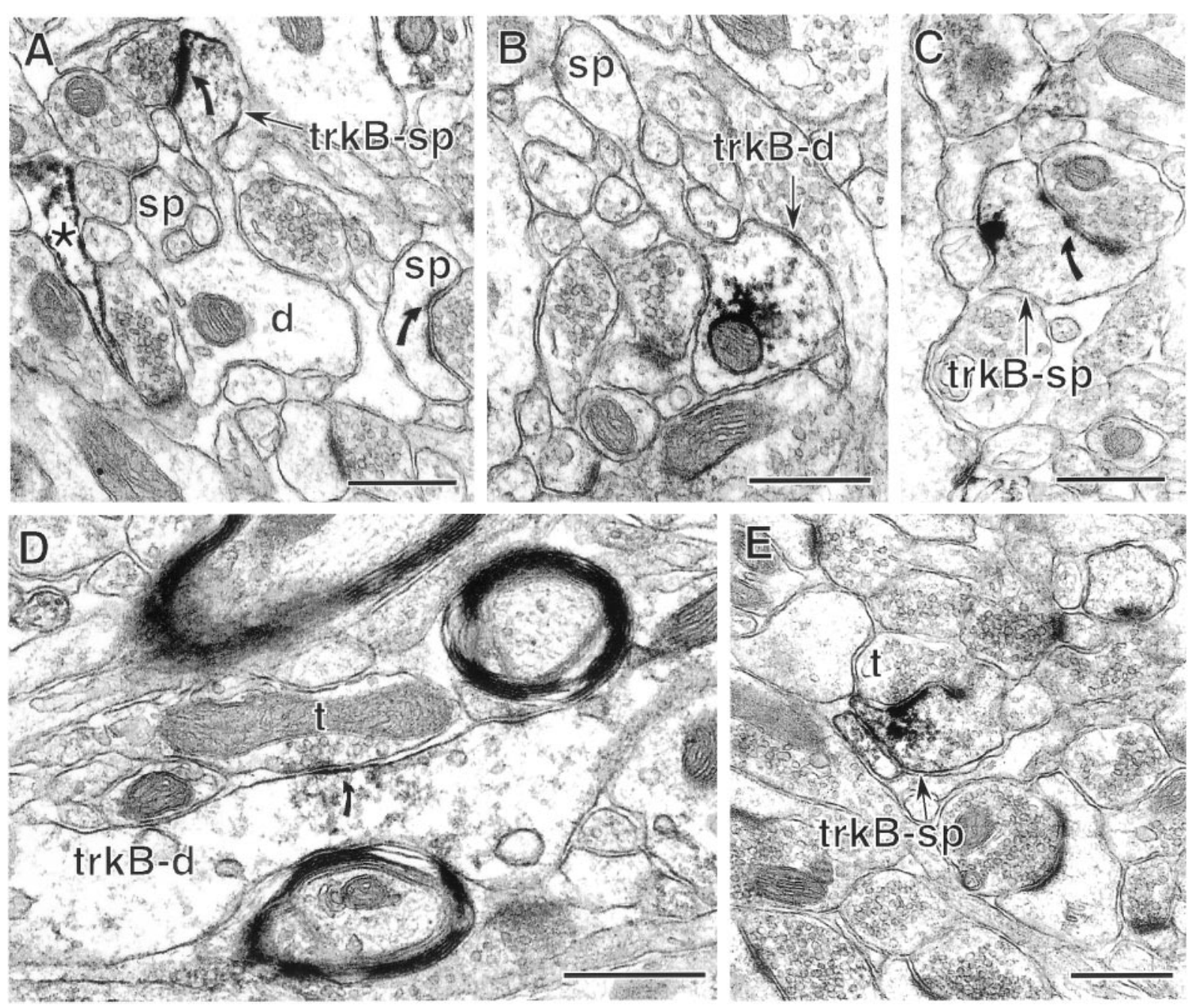

Figure 4. In the CA1 region, dendritic trkB-IR is primarily in spines and to a lesser extent in dendritic shafts. $A$, In st. radiatum, a dendritic spine contains trkB-IR (trkB-sp) along the postsynaptic density (curved arrow) and plasmalemma. In contrast, no labeling is detected in the parent dendrite of the labeled spine $(d)$ or in another spine $(s p)$ receiving an asymmetric synapse. An astrocytic process $(*)$ in this field is also labeled. $B$, In CA1 st. radiatum, a dendritic shaft $(\operatorname{trk} B-d)$ contains labeling in the cytoplasm and along a small patch of plasma membrane and extends an unlabeled spine ( $s p$ ). $C$, A spine (trkB-sp) in st. radiatum contains a cluster of trkB-IR along the plasmalemma opposite the postsynaptic density (curved arrow). $D$, A dendritic shaft $(\operatorname{trk} B-d)$ in st. lacunosum-moleculare contains trkB-IR at and near a symmetric synapse (curved arrow) from an unlabeled terminal $(t)$. $E$, A labeled dendritic spine (trkB-sp) in st. lacunosum-moleculare receives a asymmetric synapse from an unlabeled terminal $(t)$. The peroxidase reaction product is present along the postsynaptic density, nearby plasmalemma, and cytoplasmic organelles. Scale bars, $0.5 \mu \mathrm{m}$.

cholinergic septal neurons, supramammillary hypothalamic neurons, and/or other subcortical afferents (Dent et al., 1983; Clarke, 1985; Frotscher and Leranth, 1986; Milner and Bacon, 1989; Magloczky et al., 1994; Amaral and Witter, 1995; Buckmaster et al., 1996).

Within trkB-labeled terminals, immunoperoxidase labeling indicated and immunogold labeling confirmed that trkB-IR was primarily associated with small synaptic vesicles and to a lesser extent the plasma membrane (Fig. 3). In terminals as well as axons and axon initial segments, more trkB-immunoreactive sites were detected over synaptic vesicles or transport organelles than at the plasma membrane, suggesting a highly dynamic trafficking of full-length trkB receptors.

\section{Pyramidal and granule cell dendrites contain small clusters of trkB-IR}

Dendritic shafts and spines of CA1 pyramidal cells in st. oriens, st. radiatum, and st. lacunosum-moleculare contained small clusters of trkB-IR (Fig. 4). In dendritic spines, trkB-IR was usually along the plasma membrane (Fig. $4 A, C, E$ ), very often in or near the postsynaptic density of asymmetric synapses (Fig. $4 A, E$ ), and occasionally at extrasynaptic sites (Fig. $4 C$ ). In contrast, trkB labeling in the shafts of spiny dendrites was often distributed around organelles in the cytoplasm and was less frequently associated with the plasma membrane (Fig. 4B). TrkB-IR was very rarely (two examples in st. oriens) observed in dendritic shafts near symmetric synapses (Fig. 4D).

The proportions of immunolabeled dendritic spines and shafts varied between hippocampal laminae. In st. oriens, which contains basal dendrites of pyramidal cells, there was a trend toward more trkB-labeled spines than shafts, although this trend was not significant (see Fig. 9). In the pyramidal cell apical dendritic field, st. radiatum contained slightly more labeled spines than shafts, whereas st. lacunosum-moleculare contained more labeled shafts than spines (Fig. 9). In all three laminae most of the labeled dendrites resembled previous descriptions of pyramidal cell dendrites (Harris and Kater, 1994), although some trkB-labeled 

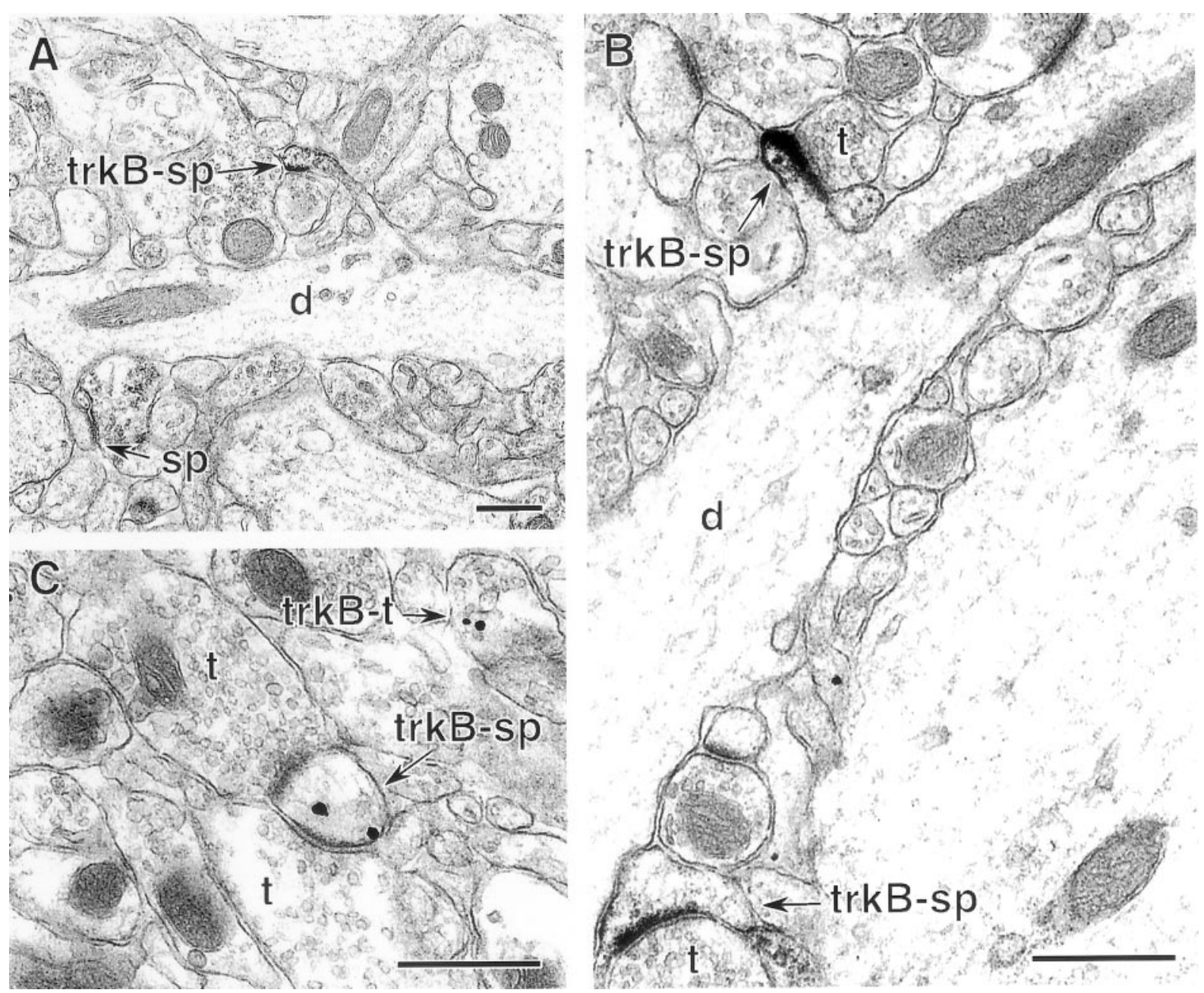

Figure 5. In dentate gyrus, trkB-IR is occasionally detected in spiny dendrites. $A$, In st. moleculare, a dendrite $(d)$ extends one trkB-labeled spine $(\operatorname{trk} B-s p)$ and one unlabeled spine $(s) . B$, In the hilus, two spines with trkB-immunoperoxidase labeling (trkB-sp) receive asymmetric synapses from unlabeled terminals $(t)$. Immunoperoxidase reaction product is present along postsynaptic densities, the plasmalemma, and intracellular organelles. The dendritic shaft $(d)$ giving rise to the upper labeled spine lacks trkB-IR. $C$, TrkB-immunogold labeling in a dendritic spine $(t r k B$-sp) in the hilus. This spine receives synapses from two unlabeled terminals $(t)$. Immunogold particles are located along the plasmalemma near one postsynaptic density and over an unidentifiable intracellular organelle. A nearby terminal $(\operatorname{trk} B-t)$ also contains trkB-IR affiliated with synaptic vesicles. Scale bars, $0.5 \mu \mathrm{m}$.

dendritic shafts lacked distinguishing features and thus may have belonged either to pyramidal neurons or to interneurons.

In the dentate gyrus, sparse trkB-IR was observed occasionally in spiny dendrites identical to previous descriptions of granule cell dendrites (Ramon y Cajal, 1911; Desmond and Levy, 1982; Claiborne et al., 1990) in outer, middle, and inner portions of st. moleculare (Fig. 5A), and to a lesser extent in st. granulosum. The frequency of trkB-IR in dendritic spines versus shafts was not significantly different (see Fig. 10). Spines contained trkB-IR along postsynaptic densities and plasma membranes, whereas shafts contained trkB-IR over cytoplasmic organelles and often along the plasma membrane. This is in contrast to labeled CA1 pyramidal cell dendrites, which rarely contained patches of trkB-IR along the plasma membrane of shafts.

\section{TrkB-IR is light and infrequent in neuronal somata}

Somatic labeling was detected only rarely at the EM level. When present, trkB-IR was usually associated with cytoplasmic vesicular organelles, mitochondria, and rough endoplasmic reticulum (Fig. 2A-C; see Fig. $7 C$ ), or in discrete patches along the plasma membrane (sometimes near symmetric synapses). Nuclear label- ing was very light (Fig. $2 E$ ) or not detectable (Fig. 6A) in most neurons, although in sections that were not counterstained and thus possessed lower electron densities, light nuclear trkB labeling was detected more frequently. Endosomes within perikarya and proximal dendrites also contained trkB-IR, but the presence of endosomal labeling in preadsorption controls indicates that a substantial portion of endosomal labeling was nonspecific. As previously noted by others (Venkatesan et al., 1996), the difference in apparent somatic labeling density observed with light versus electron microscopy is probably attributable to the LM enhancement of labeling density in large structures provided by the greater depth of field, whereas in the ultrathin sections examined by EM such low-abundance labeling is sparse.

\section{Some nonglutamatergic neurons contain trkB-IR}

In both CA1 and the dentate gyrus, trkB-IR was present in the axon initial segments of some nonprincipal cells. As in pyramidal and granule cells, trkB-IR in nonprincipal cell axon initial segments began abruptly at the transition from the somata and was concentrated along microtubule fascicles and the plasma membrane (Fig. $6 A$ ). In the CA1 region, intense trkB-IR was detected 

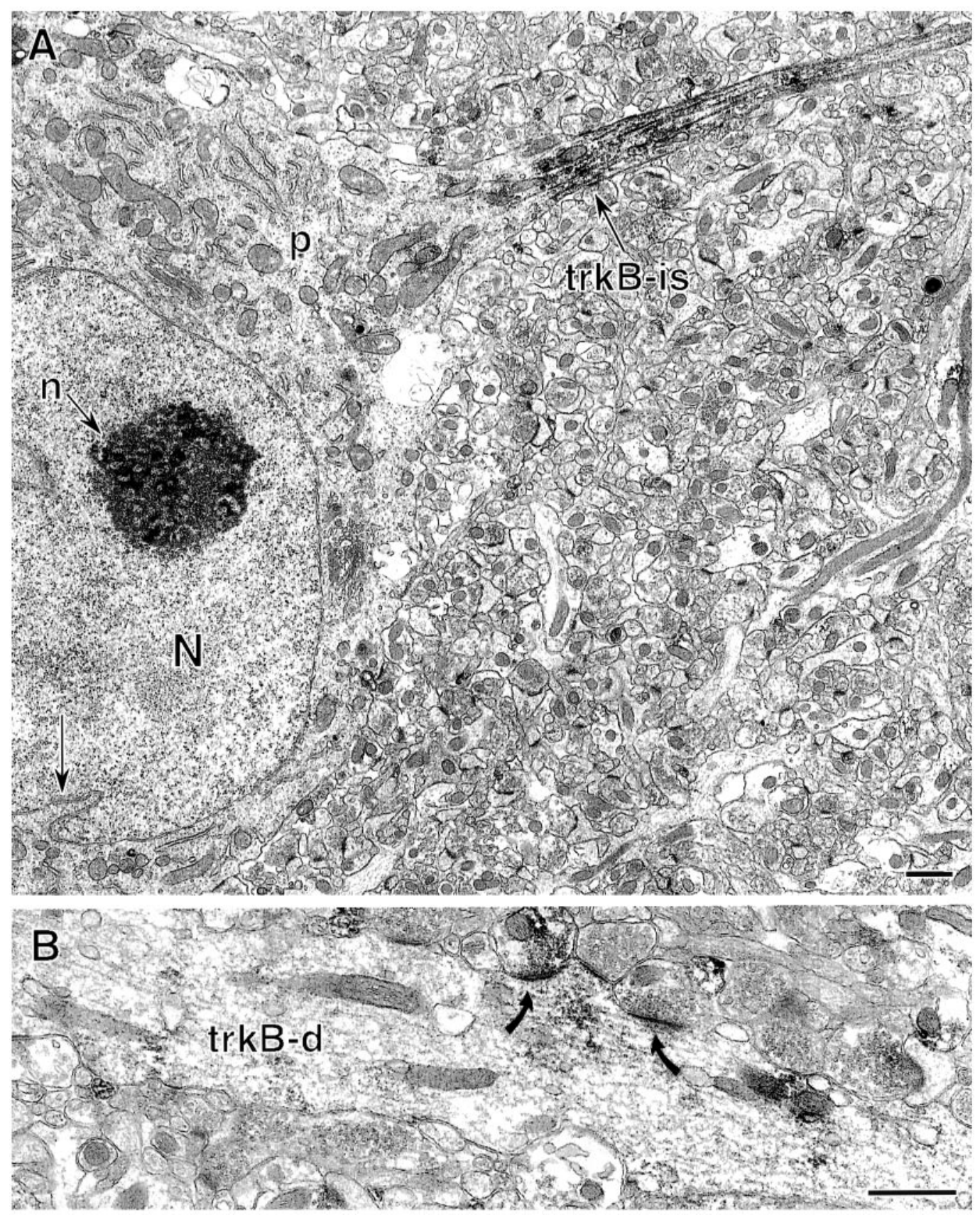

Figure 6. Some nonprincipal neurons contain intense trkB-IR. $A$, An interneuron in st. oriens of the CA1 region contains intense trkB-IR in the axon initial segment (trkB-is). This nonprincipal cell exhibits the nuclear infolding (arrow) characteristic of interneurons. The somatic perikaryon ( $p$ ) lacks detectable trkB-labeling. $N$, Nucleus, $n$, nucleolus. $B$, An interneuron dendrite $(t r k B-d)$ in st. oriens contains diff use trkB-IR. Several terminals, one of which is also trkB-labeled, form asymmetric synapses (curved arrows) with the trkB-labeled dendrite. Scale bars, $1 \mu \mathrm{m}$.

in axon initial segments of some interneurons in st. oriens (Fig. $6 A$ ) and st. radiatum (data not shown). In addition to their location outside of st. pyramidale, these cells could be positively identified as interneurons by their somatic morphology, particularly the characteristic infolded nucleus (Fig. $6 A$ ). In the dentate gyrus, labeled axon initial segments were observed in the hilus but not in st. moleculare. In the hilus, none of the labeled initial segments observed were continuous with somata in the plane of section analyzed or in available adjacent sections, so it was not possible to determine whether these originated from excitatory mossy cells or inhibitory interneurons.
Some inhibitory-type axon terminals in both the CA1 and the dentate gyrus contained trkB labeling, although such terminals were less common than labeled excitatory-type terminals (Table 1). Labeled inhibitory-type axon terminals typically contained dense accumulations of trkB-IR and formed symmetric synapses with dendritic shafts and somata of both pyramidal and granule cells and interneurons (Fig. 7A-C).

TrkB-IR was observed occasionally in identified interneuron dendrites in the CA1 region. These interneuron dendrites lacked spines and received numerous asymmetric synapses and occasional symmetric synapses on their shafts. In contrast, dendrites 

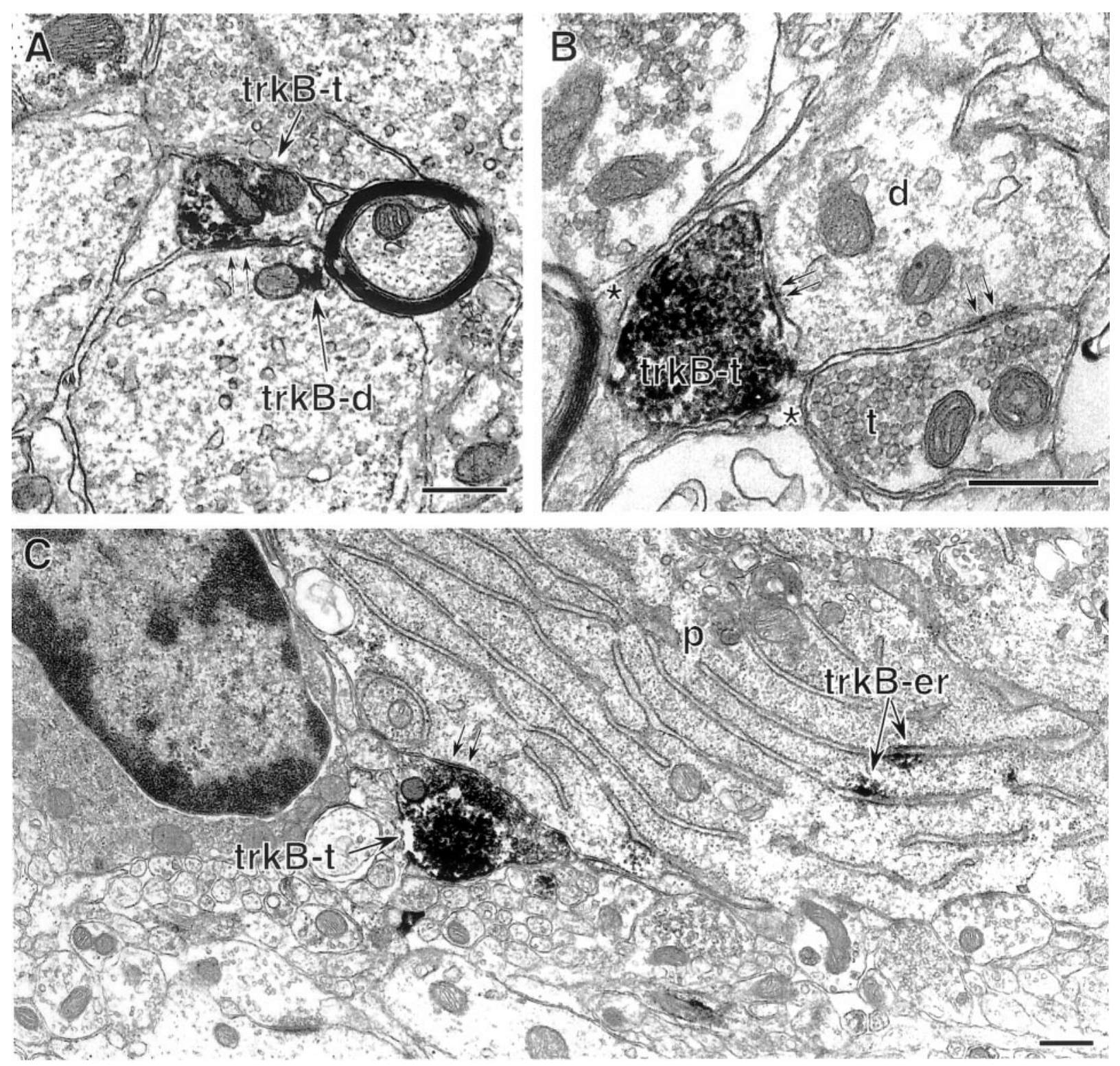

Figure 7. Some inhibitory-type axon terminals in the hippocampus and dentate gyrus contain dense trkB-IR. $A$, A labeled axon terminal (trkB-t) in st. pyramidale of the CA1 region forms an inhibitory-type synapse (parallel arrows) with a large labeled dendrite (trkB- $d$ ) containing a small patch of trkB immunoprecipitate (arrow). $B$, In the hilus of the dentate gyrus, an intensely labeled terminal (trkB-t) and an unlabeled terminal $(t)$ form symmetric synapses (parallel arrows) with an unlabeled dendrite $(d)$. Other surfaces of the labeled terminal appose glial processes $(*)$. $C$, At the hilus-st. granulosum interface in the dentate gyrus, a densely labeled terminal (trkB-t) forms a symmetric synapse (parallel arrows) with a granule cell perikaryon ( $p$ ) containing trkB-immunolabeled rough endoplasmic reticulum (trkB-er). Scale bars $0.5 \mu \mathrm{m}$.

of the glutamatergic pyramidal cells receive most asymmetric synapses onto spines and receive primarily symmetric synapses on their shafts. Only very rarely was trkB-IR in serendipitously sectioned dendrites that could be clearly identified as interneurons (Fig. 6B), although trkB-IR was regularly observed in dendritic profiles that lacked spines in the plane of section (Fig. 4D).

In the dentate gyrus, trkB-labeled interneuron dendrites were not definitively identified. In the hilus, most trkB-labeled dendritic structures extended spines or were themselves spines (Fig. $5 B, C)$. Some of these were synaptically contacted by mossy fiber terminals and clearly resembled dendrites of mossy cells, an excitatory glutamate-containing cell population with somata and spiny dendrites in the hilus (Ramon y Cajal, 1911; Amaral, 1978; Ribak et al., 1985). Other dendritic spines with trkB-IR were less distinctive and may have belonged either to mossy cells or to a population of spiny hilar interneurons (Freund and Buzsaki, 1996).

\section{TrkB $B_{23-36}$ labeling is in the same neuron populations as trkB-IR but is concentrated at different subcellular sites}

By EM, trkB ${ }_{23-36}$ antiserum was observed in pyramidal cells (Fig. $8 A)$, granule cells, some interneurons, and some glial profiles (Fig. $8 B$ ). Within neurons, trkB ${ }_{23-36}$ labeling was present in all the cellular compartments that contained full-length trkB-IR: somata (Fig. 8A), dendritic shafts (Fig. $8 D$ ), dendritic spines (Fig. $8 C$ ), axon initial segments (Fig. $8 A$ ), axons (Fig. $8 B$ ), and terminals (data not shown). However, the relative density and fre- 

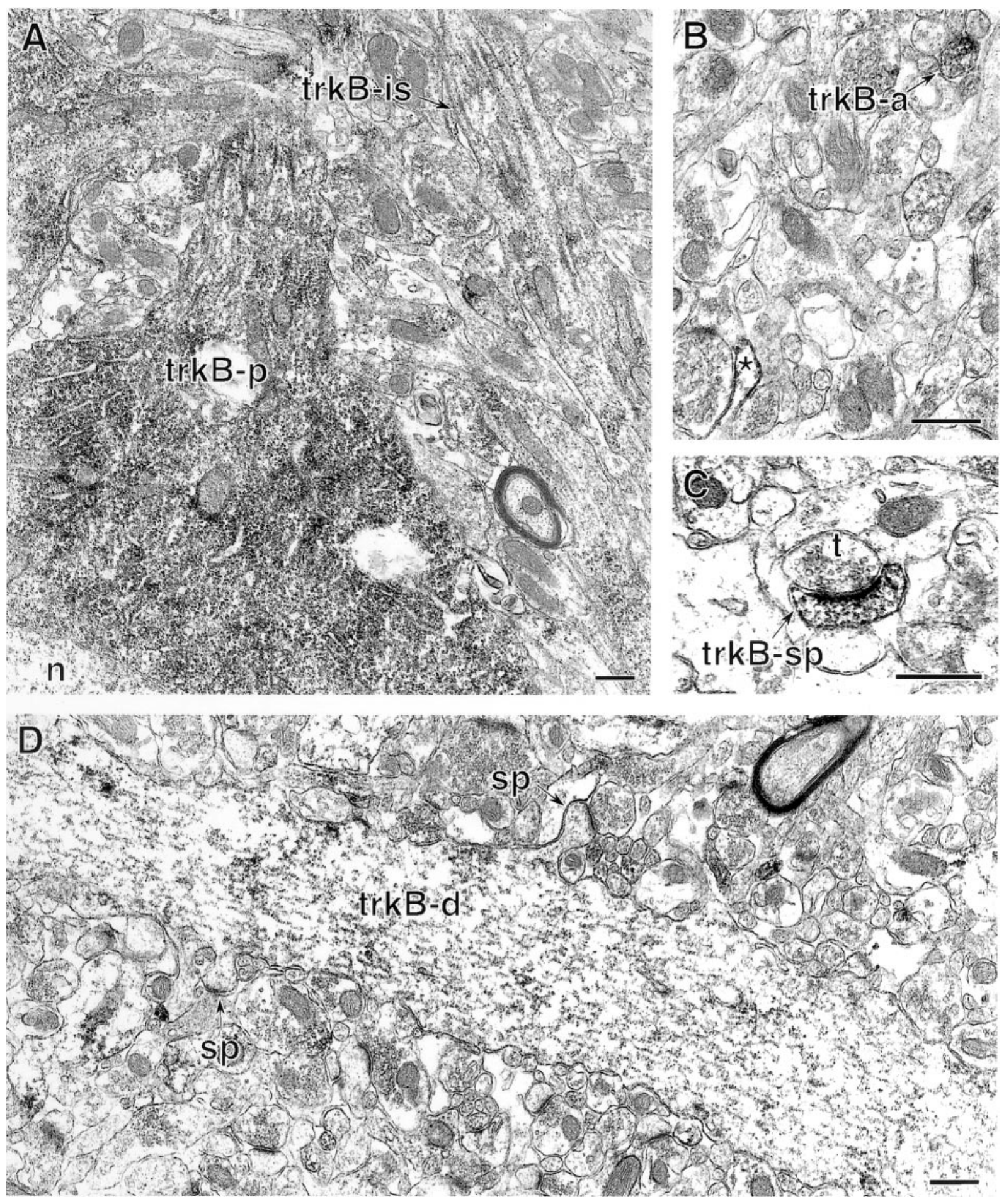

Figure 8. The distribution of $\operatorname{trkB}_{23-36}$ labeling overlaps that of the full-length-specific trkB antibody but is concentrated in different subcellular compartments. $A$. In st. pyramidale of the CA1 region, dense trkB ${ }_{23-36}$-immunogold labeling is present in a pyramidal cell perikaryon $($ trk $B$ - $p$ ). The nucleus $(n)$ is unlabeled. An adjacent axon initial segment (trkB-is) contains light immunoreactivity along microtubule bundles. $B$, In st. radiatum, $\operatorname{trkB}_{23-36}$ is present in an axon $(\operatorname{trk} B-a)$ and a glial process $\left(^{*}\right)$. $C, \mathrm{~A}$ trkB $\mathrm{B}_{23-36}$-labeled dendritic spine (trkB-sp) in st. radiatum receives an asymmetric synapse from an unlabeled terminal $(t) . D$, TrkB $23-36$ labeling in a spiny dendrite in st. radiatum. The dendritic shaft $($ trkB- $d)$ contains dense immunoreactivity and extends two unlabeled spines $(s p)$. Scale bars, $0.05 \mu \mathrm{m}$.

quency of labeling in these compartments were considerably different from those of the full-length trkB labeling. $\mathrm{TrkB}_{23-36}-\mathrm{IR}$ was common and was very dense within somata (Fig. $8 A$ ) and large dendritic shafts (Fig. $8 D$ ). Dendritic spines with trkB ${ }_{23-36}$-IR (Fig. 8C) were uncommon and less intensely labeled. Axon initial segments with trkB $23-36$ labeling (Fig. $8 A$ ) were frequently observed and were substantially less densely labeled than those with full-length-specific trkB labeling. Axons and axon terminals labeled with $\operatorname{trkB}_{23-36}$ were very infrequent and contained only very sparse trkB ${ }_{23-36}$ labeling (Fig. $8 B$ ). 

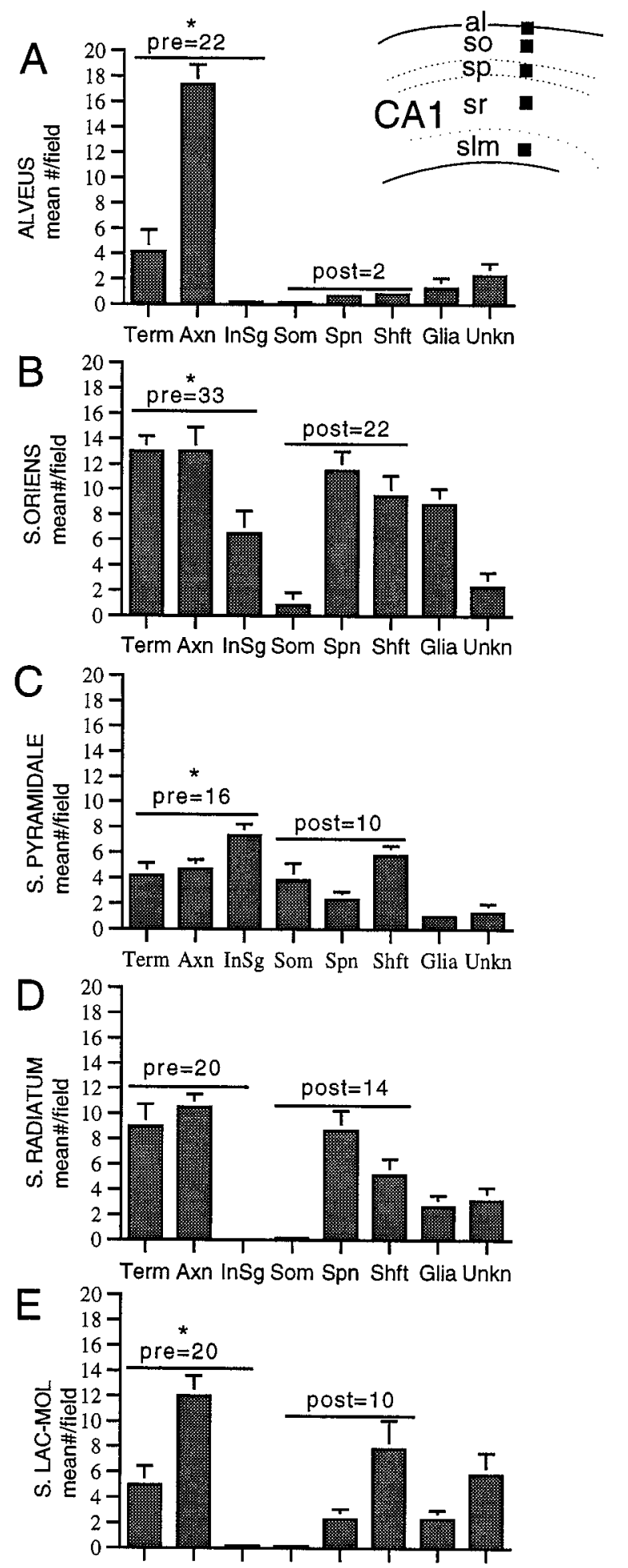

Term Axn InSg Som Spn Shft Glia Unkn

Figure 9. The number and type of profiles with trkB-IR vary between laminae in the CA1 region. Inset, From each animal $(n=3), 55 \times 55 \mu \mathrm{m}$ fields (black squares show location) were selected in two thin sections (each from a different $40 \mu \mathrm{m}$ section) in the alveus ( $a l$ ), st. oriens (so), st. pyramidale $(s p)$, st. radiatum $(s r)$, and st. lacunosum-moleculare $(s l m)$. $A-E$, Mean distribution \pm SEM of trkB-IR in terminals, axons, axon intial segments, somata, spines, shafts, glia, and unknown profiles in each lamina. Values within graphs indicate the sum of the means of presynaptic profiles (terminals, axons, and axon initial segments) and postsynaptic profiles (dendritic spines, shafts, and somata). As indicated by the

\section{TrkB labeling varies between laminae}

To determine whether trkB-IR was located more commonly in particular cellular compartments, the relative frequency was estimated for each type of trkB-labeled profile in all CA1 and dentate gyrus laminae. TrkB-IR was present in similar-sized small patches within different types of labeled profiles, with the exception of the densely labeled axon initial segments and the scarce but densely labeled terminals of putative interneurons and extrahippocampal afferents. Because every thin section through these densely labeled structures would contain label, this may have led to an overestimation of their prevalence. Because conservative criteria were used to classify profiles, a small proportion (6.7\% in CA1 and $7.5 \%$ in dentate gyrus) of profiles lacking sufficient distinguishing characteristics were classified as unknown. Most of the unknown profiles were very small $(<0.1 \mu \mathrm{m})$, round processes that resembled small axons or glial processes.

For all laminae, the number of trkB-labeled presynaptic structures (axons, initial segments, and axon terminals) was compared with labeled postsynaptic structures (dendritic spines and shafts). In the CA1 region, the alveus, st. oriens, st. pyramidale, and st. lacunosum-moleculare all contained significantly more presynaptic than postsynaptic labeled profiles (Fig. 9). However, in st. radiatum, differences between presynaptic and postsynaptic distribution were not significant (Fig. 9). In the dentate gyrus, the hilus and st. granulosum contained more presynaptic than postsynaptic labeling, whereas in the inner portion of st. moleculare, differences between presynaptic and postsynaptic labeled profiles were insignificant (Fig. 10). The observed differences may be attributable in some instances to differences in the neuropil composition: for example, the alveus contains many myelinated axons of pyramidal neurons and other neurons but few dendrites. However, in laminae with abundant profiles of both types, trkB-IR was more often detected in axons and terminals than in somata and dendrites.

Because trkB ligands have been repeatedly shown to modulate synaptic plasticity in st. radiatum (Thoenen, 1995; Bonhoeffer, 1996; Lu and Figurov, 1997), we examined the proportion of all presynaptic profiles in this lamina that contained trkB-IR. Three micrographs (one from each animal) were chosen from those used in quantifying trkB-labeled profiles, and all labeled "presynaptic" profiles (axons and terminals) were counted. Within these measured fields (ranging from 233 to $244 \mu \mathrm{m}^{2}$ ), 344-371 presynaptic profiles were present, corresponding to a density of $1.42-1.50$ presynaptic profiles $/ \mu \mathrm{m}^{2}$. An average density of 1.48 presynaptic profiles $/ \mu \mathrm{m}^{2}$ was extrapolated to the $3025 \mu \mathrm{m}^{2}$ fields in which trkB counts were made, resulting in $\sim 4477$ unlabeled and labeled presynaptic profiles $/ 3025 \mu \mathrm{m}^{2}$. Considering that on average 20 trkB-labeled presynaptic profiles were seen in this area, $\sim 1$ of 224 presynaptic profiles observed in single sections through st. radiatum contained trkB labeling. Because the discrete clusters of trkB-IR are not present in most planes of section, this is an underestimation of the actual numbers of labeled terminals. Nonetheless, the low trkB-labeling density within terminals, combined with the relatively low abundance of labeled terminals,

$\leftarrow$

asterisks, the number of trkB-labeled presynaptic profiles was significantly greater than labeled postsynaptic profiles in the alveus $(p=0.002)$, st. oriens $(p=0.002)$, st. pyramidale $(p=0.041)$, and st. lacunosummoleculare $(p=0.026)$. Labeled presynaptic and postsynaptic profiles were of similar abundance in st. radiatum $(p=0.093)$. 

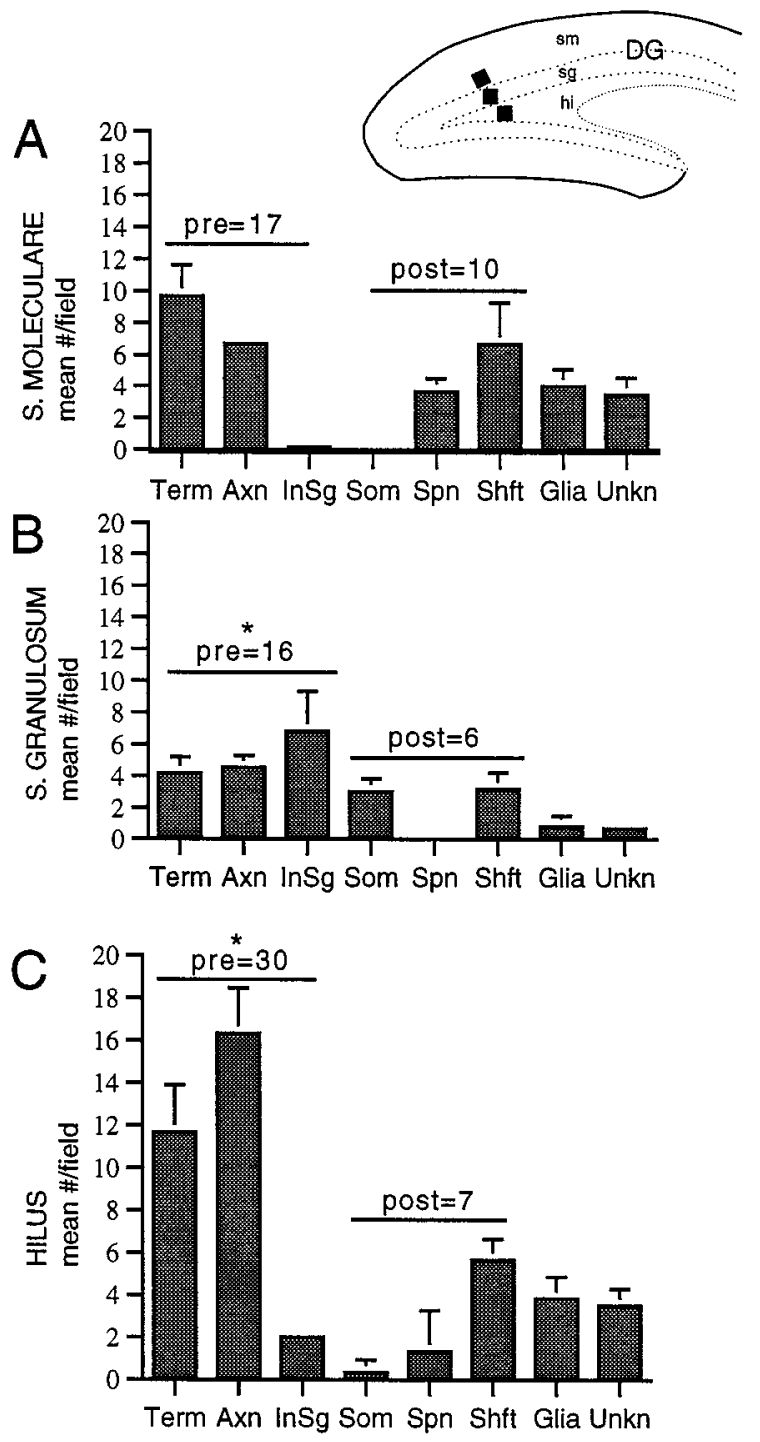

Figure 10. The number and type of profiles with trkB-IR varies between laminae in the dentate gyrus. Inset, For each animal $(n=3), 55 \times 55 \mu \mathrm{m}$ fields (black squares show location) were selected in two thin sections (each from a different $40 \mu \mathrm{m}$ section) from the subgranular zone of the hilus ( $\mathrm{hi}$ ), suprapyramidal blade of st. granulosum ( $\mathrm{s}$ ), and inner onethird of st. moleculare ( $\mathrm{sm}$ ). $A-C$, Mean number \pm SEM of trkB-IR in terminals, axons, axon intial segments, somata, spines, shafts, glia, and unknown profiles in each lamina. Values within graphs indicate the sum of the means of presynaptic profiles (terminals, axons, and axon initial segments) and postsynaptic profiles (dendritic spines, shafts, and somata). As indicated by the asterisks, trkB-labeled presynaptic profiles were significantly more numerous than labeled postsynaptic profiles in st. granulosum and the hilus ( $p=0.026$ and 0.004 , respectively) and were of similar abundance in st. moleculare $(p=0.240)$.

suggests that the distribution of full-length trkB is quite restricted.

\section{DISCUSSION}

In this study we have examined the ultrastructural localization of immunoreactivity for the full-length (catalytic) trkB receptor in the hippocampal formation. Our results are summarized in Figure 11 . We find that the catalytic trkB receptor is present within axon initial segments of several types of neurons, suggesting extensive trafficking. TrkB is also in a subset of axon terminals and dendritic spines of granule and pyramidal cells, suggesting roles in both presynaptic and postsynaptic modulation of glutamatergic neurotransmission. Furthermore, trkB is also in some nonglutamatergic neurons, indicating potential roles in inhibitory or neuromodulatory circuits as well.

\section{Catalytic trkB in the trisynaptic circuit: targeting to compartments mediating excitatory neurotransmission}

Striking accumulations of trkB labeling were seen in axon initial segments of pyramidal neurons and granule cells. Most labeling was associated with intracellular organelles, suggesting a highly dynamic trafficking of trkB receptors in the axonal compartment. Interestingly, it was recently reported that the rapid retrograde signal carried by trk receptors in sciatic neurons is vesicleassociated (Bhattacharyya et al., 1997). TrkB-IR also was observed along the plasma membrane of axon initial segments, suggesting that trkB activation might play a role in modulating the axonal propagation of action potentials from their initiation at the adjacent axon hillock.

We detected trkB-IR in a small subset of presynaptic terminals within the classic hippocampal "trisynaptic circuit," i.e., the excitatory glutamatergic circuit from perforant path terminals to dentate granule cells to CA3 pyramidal cells to CA1 pyramidal cells (Amaral and Witter, 1995). This is consistent with electrophysiological studies showing rapid, presynaptic enhancement of hippocampal synaptic transmission by BDNF, NT-3, and NT-4/5 (Leßmann et al., 1994; Kang and Schuman, 1995; Levine et al., 1995; Scharfman, 1997; Messaoudi et al., 1998). TrkB-IR in axon terminals was often over small synaptic vesicles. Neurotrophins stimulate the phosphorylation of the synaptic vesicle protein synapsin I by MAP kinase (Jovanovic et al., 1996), which may lead to mobilization of small synaptic vesicles and a subsequent increase in synaptic efficacy (Greengard et al., 1993). TrkB-IR was detected in only a small proportion of granule and pyramidal cell axon terminals and within labeled terminals was clustered in a small area. This indicates that catalytic trkB is either in selected populations of excitatory terminals or is sparsely present in many such terminals but below the threshold of detection in most planes of section. These findings suggest that a high density of presynaptic catalytic trkB receptors may not be required for profound effects on plasticity, or that although trkB can modulate presynaptic function, a portion of its role in synaptic plasticity may be postsynaptic.

A role for trkB ligands in local postsynaptic modulation of excitatory neurotransmission is suggested by the presence of trkB-IR in dendritic spines, which are the targets of glutamatergic innnervation in the trisynaptic circuit (Blackstad, 1963; Bramham et al., 1990). Physiological studies have suggested that postsynaptic trkB receptors may mediate some rapid effects of BDNF. In cultured hippocampal neurons, injection of the trk tyrosine kinase inhibitor K252a into the postsynaptic neuron partially prevents the BDNF-evoked potentiation of synaptic transmission, whereas injection of the phosphatase inhibitor okadaic acid enhances the BDNF effect (Levine et al., 1995). Furthermore, BDNF has been shown to postsynaptically diminish pyramidal cell responses to synaptically released GABA (Tanaka et al., 1997). In combination with the evidence for presynaptic trkB discussed above, these findings strongly suggest that, depending on experimental context, both presynaptic and postsynaptic effects of trkB ligands can occur.

TrkB-IR was frequently at the plasma membrane of dendritic spines, suggesting that spines are important recipients of signals 


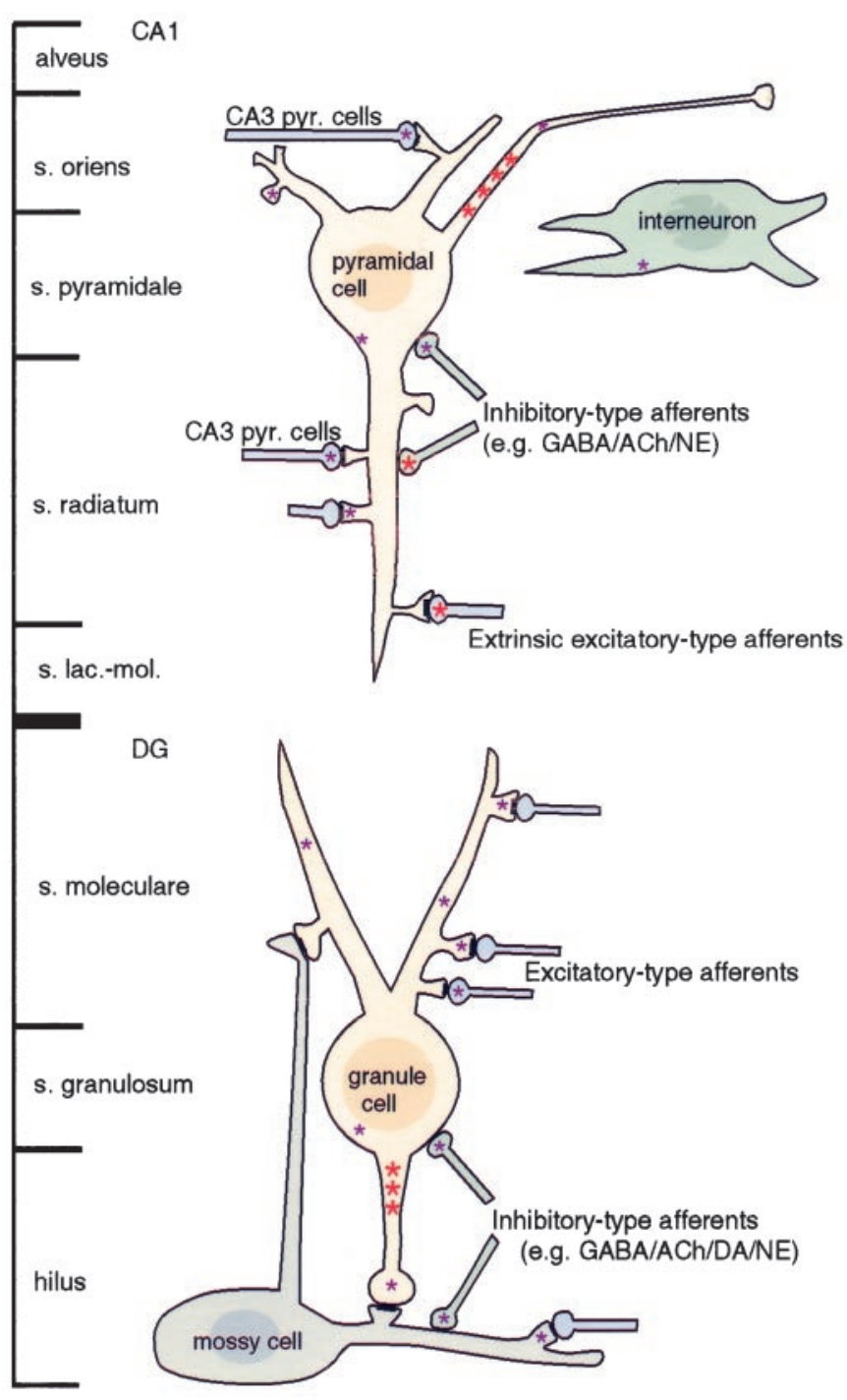

Figure 11. Summary of sites containing specific trkB labeling in the CA1 region of hippocampus and the dentate gyrus $(D G)$. Intense labeling (large red asterisks) and sparse labeling (small purple asterisks) were sometimes observed in different compartments of the same cells. Not shown: intensely labeled terminals of unidentified origin in the hilus.

transmitted by ligands such as BDNF. The intracellular distribution of trkB-IR in dendritic shafts (and to a lesser degree in spines) may represent trkB receptors in transit to and from the spines or a pool of receptors available for rapid insertion into the plasma membrane of either shaft or spine. Such rapid insertion was recently demonstrated in cultured retinal neurons, in which excitatory stimuli (depolarization or cAMP elevation) triggered the translocation of trkB-IR from cytoplasm to plasma membrane (Meyer-Franke et al., 1998). This could represent a mechanism for relatively rapid enhancement of postsynaptic sensitivity to incoming signals, reminiscent of the AMPA receptor insertion postulated to underlie "silent synapse" conversion (Liao et al., 1995).

\section{TrkB in extrahippocampal afferents and GABAergic} interneurons: different roles than in principal cells?

We also found extensive anatomical evidence that trkB ligands may play a role in modulating the effects of GABAergic interneurons and input from extrahippocampal afferents. Intense
trkB-IR was present in some interneuron axon initial segments and in axon terminals that formed inhibitory-type (symmetric) synapses characteristic of GABAergic, cholinergic, and monoaminergic terminals. The localization of trkB-IR to hippocampal interneurons is consistent with previous findings that some interneurons contain trkB mRNA (Zachrisson et al., 1996) and respond to BDNF (Marty et al., 1996). BDNF also has been shown to enhance acetylcholine release from hippocampal synaptosomes (Knipper et al., 1994). TrkB labeling also was detected in some excitatory-type axon terminals resembling those known to arise from extrahippocampal afferents (Amaral and Witter, 1995). These terminals, which may contain glutamate and/or neuromodulators, were much more intensely labeled than terminals of the trisynaptic circuit.

The dense labeling of afferent and probable interneuron axon terminals suggests that trkB ligands may be playing different roles in these populations than in granule and pyramidal neurons. For example, intense accumulations of trkB receptor might reflect a need for high levels of trophic support. Neurotrophins are known to have trophic actions on GABAergic interneurons (Marty et al., 1996) and septal afferents containing GABA (Rocamora et al., 1996) and acetylcholine (Alderson et al., 1990; Knüsel et al., 1991; Wetmore et al., 1991; DiStefano et al., 1992; Burke et al., 1994), as well as some serotonergic, dopaminergic, and noradrenergic neurons (Altar et al., 1994; Mamounas et al., 1995; Sklair-Tavron and Nestler, 1995; Spenger et al., 1995). Another interesting possibility is that these inhibitory and modulatory neurons may themselves be subject to modulation by trkB ligands, resembling the recently proposed "metaplasticity," which may regulate the ability of neurons to alter synaptic efficacy (Abraham and Bear, 1996). The precise determination of which afferent populations contain catalytic trkB awaits future dual-labeling studies.

\section{Patterns of full-length trkB-IR complement pan-trkB localizations and overlap the distribution of BDNF-IR}

Previous LM studies using the $\operatorname{trkB}_{23-36}$ antibody, which recognizes both full-length and truncated trkB receptors, have reported considerable labeling of dendritic shafts of pyramidal cells but no detectable labeling of spines, axon initial segments, or terminals (Fryer et al., 1996; Yan et al., 1997). Using the higher resolution afforded by EM, we observed sparse labeling of a few spines, initial segments, axons, and terminals in addition to the dense labeling of somata and dendritic shafts. The apparent lack of labeled spines and terminals in previous reports may have been partially attributable to the lower sensitivity of light microscopy to sparsely labeled small structures. Additionally, if the $\operatorname{trkB}_{23-36}$ antibody mainly recognizes truncated trkB receptors in fixed tissue (see Results), this suggests that the truncated trkB receptors are mainly in somata and dendritic shafts. In contrast, fulllength trkB receptors appear to be concentrated predominantly in axons, terminals, and dendritic spines. Functionally, truncated trkB receptor might limit the diffusion of trkB ligands (Bothwell, 1995), preventing access to distant terminals and/or spines. Although data on the subcellular localization of different trkB forms during development are not yet available, the developmental increase in the ratio of truncated to full-length trkB (Allendoerfer et al., 1994; Fryer et al., 1996) is consistent with truncated trkB serving to increasingly restrict access to trkB ligands during maturation.

The trkB ligand BDNF has previously been localized by LM (Wetmore et al., 1991; Dugich-Djordjevic et al., 1995; Conner et al., 1997; Yan et al., 1997). In the CA1 region, BDNF-IR was 
more abundant in st. oriens and st. radiatum, where we often observed trkB-IR. In the dentate gyrus, BDNF-IR, like trkB-IR, was most abundant in the hilus, followed by the inner portion of st. moleculare. These findings demonstrate an excellent match between immunoreactivity for catalytic trkB and its ligand BDNF and are consistent with functional, relatively local, interactions between endogenous BDNF and the full-length trkB receptor in adult rat hippocampal formation.

\section{Implications for activity-dependent plasticity}

The discrete clusters of labeling for full-length trkB on excitatorytype terminals and dendritic spines in the trisynaptic circuit imply spatially restricted effects of trkB ligands. Such spatial restriction of neurotrophin action would be expected if trkB ligands are playing a role in selectively modulating active synapses. Activitydependent secretion of NT-4/5 by cultured myocytes can evoke highly localized potentiation of synaptic transmission (Wang et al., 1998), suggesting that the initial, localized actions of secreted neurotrophins could help establish the transient "synaptic tag" suggested to be critical for the late phase of LTP (Frey and Morris, 1997).

During the activity-dependent refinement of cytoarchitecture in the developing visual and cerebellar systems, neurotrophins modulate both axon outgrowth and higher-order dendritic branching and spine formation (Cabelli et al., 1995, 1997; McAllister et al., 1995, 1996, 1997; Morrison and Mason, 1998). In the adult, the limited structural data available suggest that the later phases of LTP may be expressed as changes in dendritic spine shapes and/or synaptic morphology (Stanton, 1996). By analogy to the effects of neurotrophins on dendrite and spine structure during development, neurotrophins acting through full-length trkB receptors on dendritic spines and terminals might contribute to the activity-dependent refinement of hippocampal connections during adult synaptic plasticity.

\section{REFERENCES}

Abraham WC, Bear MF (1996) Metaplasticity: the plasticity of synaptic plasticity. Trends Neurosci 19:126-130.

Alderson RF, Alterman AL, Barde YA, Lindsay RM (1990) Brainderived neurotrophic factor increases survival and differentiated functions of rat septal cholinergic neurons in culture. Neuron 5:297-306.

Alkondon M, Pereira EF, Barbosa CT, Albuquerque EX (1997) Neuronal nicotinic acetylcholine receptor activation modulates gammaaminobutyric acid release from CA1 neurons of rat hippocampal slices. J Pharmacol Exp Ther 283:1396-1411.

Allendoerfer KL, Cabelli RJ, Escandon E, Kaplan DR, Nikolics K, Shatz CJ (1994) Regulation of neurotrophin receptors during the maturation of the mammalian visual system. J Neurosci 14:1795-1811.

Altar CA, DiStefano PS (1998) Neurotrophin trafficking by anterograde transport. Trends Neurosci 21:433-437.

Altar CA, Boylan CB, Fritsche M, Jackson C, Hyman C, Lindsay RM (1994) The neurotrophins NT-4/5 and BDNF augment serotonin, dopamine, and GABAergic systems during behaviorally effective infusions to the substantia nigra. Exp Neurol 130:31-40.

Amaral DG (1978) A Golgi study of the cell types in the hilar region of the hippocampus in the rat. J Comp Neurol 182:851-914.

Amaral DG, Witter MP (1995) Hippocampal formation. In: The rat nervous system (Paxinos G, ed), pp 443-493. San Diego: Academic.

Andrade R, Malenka RC, Nicoll RA (1986) A G-protein couples serotonin and $\mathrm{GABA}_{\mathrm{B}}$ receptors to the same channels in hippocampus. Science 234:1261-1265.

Bhattacharyya A, Watson FL, Bradlee TA, Pomeroy SL, Stiles CD, Segal RA (1997) Trk receptors function as rapid retrograde signal carriers in the adult nervous system. J Neurosci 17:7007-7016.

Blackstad TW (1963) Ultrastructural studies on the hippocampal region. In: Progress in brain research, Vol 3 (Bargmann W, Schade JP, eds), pp 122-148. New York: Elsevier.
Bonhoeffer T (1996) Neurotrophins and activity-dependent development of the neocortex. Curr Opin Neurobiol 6:119-126.

Bothwell M (1995) Functional interactions of neurotrophins and neurotrophin receptors. Annu Rev Neurosci 18:223-253.

Bramham CR, Torp R, Zhang N, Storm-Mathisen J, Ottersen OP (1990) Distribution of glutamate-like immunoreactivity in excitatory hippocampal pathways: a semiquantitative electron microscopic study in rats. Neuroscience 39:405-417.

Bramham CR, Southard T, Sarvey JM, Herkenham M, Brady LS (1996) Unilateral LTP triggers bilateral increases in hippocampal neurotrophin and trk receptor mRNA expression in behaving rats: evidence for interhemispheric communication. J Comp Neurol 368:371-382.

Buckmaster PS, Strowbridge BW, Schwartzkroin PA (1993) A comparison of rat hippocampal mossy cells and CA3c pyramidal cells. J Neurophysiol 70:1281-1299.

Buckmaster P, Wenzel H, Kunkel D, Schwarztkroin P (1996) Axon arbors and synaptic connections of hippocampal mossy cells in the rat in vivo. J Comp Neurol 366:270-292.

Burke MA, Mobley WC, Cho J, Wiegand SJ, Lindsay RM, Mufson EJ, Kordower JH (1994) Loss of developing cholinergic basal forebrain neurons following excitotoxic lesions of the hippocampus: rescue by neurotrophins. Exp Neurol 130:178-195.

Cabelli RJ, Hohn A, Shatz CJ (1995) Inhibition of ocular dominance column formation by infusion of NT-4/5 or BDNF. Science 267:1662-1666.

Cabelli RJ, Shelton DL, Segal RA, Shatz CJ (1997) Blockade of endogenous ligands of trkB inhibits formation of ocular dominance columns. Neuron 19:63-76.

Castren E, Pitkanen M, Sirvio J, Parsadanian A, Lindholm D, Thoenen H, Riekkinen PJ (1993) The induction of LTP increases BDNF and NGF mRNA but decreases NT-3 mRNA in the dentate gyrus. NeuroReport 4:895-898.

Chan J, Aoki C, Pickel VM (1990) Optimization of differential immunogold-silver and peroxidase labeling with maintenance of ultrastructure in brain sections before plastic embedding. J Neurosci Methods 33:113-127.

Claiborne BJ, Amaral DG, Cowan WM (1986) A light and electron microscopic analysis of the mossy fibers of the rat dentate gyrus. J Comp Neurol 246:435-458.

Claiborne BJ, Amaral DG, Cowan WM (1990) Quantitative, threedimensional analysis of granule cell dendrites in the rat dentate gyrus. J Comp Neurol 302:206-219.

Clarke DJ (1985) Cholinergic innervation of the rat dentate gyrus: an immunocytochemical and electron microscopical study. Brain Res 360:349-354

Conner JM, Lauterborn JC, Yan Q, Gall CM, Varon S (1997) Distribution of brain-derived neurotrophic factor (BDNF) protein and mRNA in the normal adult rat CNS: evidence for anterograde axonal transport. J Neurosci 17:2295-2313.

Dent JA, Galvin NJ, Stanfield BB, Cowan WM (1983) The mode of termination of the hypothalamic projection to the dentate gyrus. Brain Res 258:1-10.

Desmond NL, Levy WB (1982) A quantitative anatomical study of the granule cell dendritic fields of the rat dentate gyrus using a novel probabilistic method. J Comp Neurol 212:131-145.

Desmond NL, Scott CA, Jane JJ, Levy WB (1994) Ultrastructural identification of entorhinal cortical synapses in CA1 stratum lacunosummoleculare of the rat. Hippocampus 4:594-600.

DiStefano PS, Friedman B, Radziejewski C, Alexander C, Boland P, Schick CM, Lindsay RM, Wiegand SJ (1992) The neurotrophins BDNF, NT-3, and NGF display distinct patterns of retrograde axonal transport in peripheral and central neurons. Neuron 8:983-993.

Dolleman-Van der Weel M, Lopes da Silva F, Witter MP (1997) Nucleus reuniens thalami modulates activity in hippocampal field CA1 through excitatory and inhibitory mechanisms. J Neurosci 17:5640-5650.

Dragunow M, Hughes P, Mason-Parker SE, Lawlor P, Abraham WC (1997) TrkB expression in dentate granule cells is associated with a late phase of long-term potentiation. Brain Res Mol Brain Res 46:274-80.

Drake CT, Patterson TA, Simmons ML, Chavkin C, Milner TA (1996) Kappa opioid receptor-like immunoreactivity in guinea pig brain: ultrastructural localization in presynaptic terminals in hippocampal formation. J Comp Neurol 370:377-395.

Dugich-Djordjevic MM, Peterson C, Isono F, Ohsawa F, Widmer HR, Denton TL, Bennett GL, Hefti F (1995) Immunohistochemical visu- 
alization of brain-derived neurotrophic factor in the rat brain. Eur J Neurosci 7:1831-1839.

Eldred WD, Zucker C, Karten HJ, Yazulla S (1983) Comparison of fixation and penetration enhancement techniques for use in ultrastructural immunocytochemistry. J Histochem Cytochem 31:285-292.

Fawcett JP, Bamji SX, Causing CG, Aloyz R, Ase AR, Reader TA, McLean JH, Miller FD (1998) Functional evidence that BDNF is an anterograde neuronal trophic factor in the CNS. J Neurosci 18:2808-2821.

Figurov A, Pozzo-Miller LD, Olafsson P, Wang T, Lu B (1996) Regulation of synaptic responses to high-frequency stimulation and LTP by neurotrophins in the hippocampus. Nature 381:706-709.

Freund T, Buzsaki G (1996) Interneurons of the hippocampus. Hippocampus 6:347-470.

Frey U, Morris RG (1997) Synaptic tagging and long-term potentiation [see comments]. Nature 385:533-536.

Friedman WJ, Black IB, Kaplan DR (1998) Distribution of the neurotrophins brain-derived neurotrophic factor, neurotrophin-3, and neurotrophin- $4 / 5$ in the postnatal rat brain: an immunocytochemical study. Neuroscience 84:101-114.

Frotscher M, Leranth C (1986) The cholinergic innervation of the rat fascia dentata: identification of target structures on granule cells by combining choline acetyltransferase immunocytochemistry and Golgi impregnation. J Comp Neurol 243:58-70.

Fryer RH, Kaplan DR, Feinstein SC, Radeke MJ, Grayson DR, Kromer LF (1996) Developmental and mature expression of full-length and truncated TrkB receptors in the rat forebrain. J Comp Neurol 374:21-40.

Gall C, Lauterborn J (1992) The dentate gyrus: a model system for studies of neurotrophin regulation. Epilepsy Res [Suppl] 7:171-185.

Greengard P, Valtorta F, Czernik AJ, Benfenati F (1993) Synaptic vesicle phosphoproteins and regulation of synaptic function. Science 259:780-785.

Harris K, Kater S (1994) Dendritic spines: cellular specializations imparting both stability and flexibility to synaptic function. Annu Rev Neurosci 17:341-371.

Hsu S, Raine L, Fanger H (1981) Use of avidin-biotin-peroxidase complex $(\mathrm{ABC})$ in immunoperoxidase techniques: a comparison between $\mathrm{ABC}$ and unlabeled antibody (PAP) procedures. J Histochem Cytochem 29:577-580.

Jovanovic JN, Benfenati F, Siow YL, Sihra TS, Sanghera JS, Pelech SL, Greengard P, Czernik AJ (1996) Neurotrophins stimulate phosphorylation of synapsin I by MAP kinase and regulate synapsin I-actin interactions. Proc Natl Acad Sci USA 93:3679-3683.

Kang H, Schuman EM (1995) Long-lasting neurotrophin-induced enhancement of synaptic transmission in the adult hippocampus. Science 267:1658-1662.

Kang H, Schuman EM (1996) A requirement for local protein synthesis in neurotrophin-induced hippocampal synaptic plasticity. Science 273:1402-1406.

Klein R, Conway D, Parada LF, Barbacid M (1990) The trkB tyrosine protein kinase gene codes for a second neurogenic receptor that lacks the catalytic kinase domain. Cell 61:647-656.

Knipper M, da Penha Berzaghi M, Blochl A, Breer H, Thoenen H, Lindholm D (1994) Positive feedback between acetylcholine and the neurotrophins nerve growth factor and brain-derived neurotrophic factor in the rat hippocampus. Eur J Neurosci 6:668-671.

Knüsel B, Winslow JW, Rosenthal A, Burton LE, Seid DP, Nikolics K, Hefti F (1991) Promotion of central cholinergic and dopaminergic neuron differentiation by brain-derived neurotrophic factor but not neurotrophin 3. Proc Natl Acad Sci USA 88:961-965.

Kokaia Z, Bengzon J, Metsis M, Kokaia M, Persson H, Lindvall O (1993) Coexpression of neurotrophins and their receptors in neurons of the central nervous system. Proc Natl Acad Sci USA 90:6711-6715.

Korte M, Carroll P, Wolf E, Brem G, Thoenen H, Bonhoeffer T (1995) Hippocampal long-term potentiation is impaired in mice lacking brainderived neurotrophic factor. Proc Natl Acad Sci USA 92:8856-8860.

Korte M, Staiger V, Griesbeck O, Thoenen H, Bonhoeffer T (1996) The involvement of brain-derived neurotrophic factor in hippocampal longterm potentiation revealed by gene targeting experiments. J Physiol (Paris) 90:157-164.

Lamballe F, Klein R, Barbacid M (1991) trkC, a new member of the trk family of tyrosine protein kinases, is a receptor for neurotrophin-3. Cell 66:967-979.

Leßmann V, Gottmann K, Heumann R (1994) BDNF and NT-4/5 en- hance glutamatergic synaptic transmission in cultured hippocampal neurones. NeuroReport 6:21-25.

Levine ES, Dreyfus CF, Black IB, Plummer MR (1995) Brain-derived neurotrophic factor rapidly enhances synaptic transmission in hippocampal neurons via postsynaptic tyrosine kinase receptors. Proc Natl Acad Sci USA 92:8074-8077.

Liao D, Hessler NA, Malinow R (1995) Activation of postsynaptically silent synapses during pairing-induced LTP in CA1 region of hippocampal slice. Nature 375:400-404.

Lo DC (1995) Neurotrophic factors and synaptic plasticity. Neuron 15:979-981.

Lu B, Figurov A (1997) Role of neurotrophins in synapse development and plasticity. Rev Neurosci 8:1-12.

Magloczky Z, Acsady L, Freund TF (1994) Principal cells are the postsynaptic targets of supramammillary afferents in the hippocampus of the rat. Hippocampus 4:322-334.

Mamounas LA, Blue ME, Siuciak JA, Altar CA (1995) Brain-derived neurotrophic factor promotes the survival and sprouting of serotonergic axons in rat brain. J Neurosci 15:7929-7939.

Marchi M, Bocchieri P, Garbarino L, Raiteri M (1989) Muscarinic inhibition of endogenous glutamate release from rat hippocampus synaptosomes. Neurosci Lett 96:229-234.

Marty S, Berninger B, Carroll P, Thoenen H (1996) GABAergic stimulation regulates the phenotype of hippocampal interneurons through the regulation of brain-derived neurotrophic factor. Neuron 16:565-570.

McAllister AK, Lo DC, Katz LC (1995) Neurotrophins regulate dendritic growth in developing visual cortex. Neuron 15:791-803.

McAllister AK, Katz LC, Lo DC (1996) Neurotrophin regulation of cortical dendritic growth requires activity. Neuron 17:1057-1064.

McAllister AK, Katz LC, Lo DC (1997) Opposing roles for endogenous BDNF and NT-3 in regulating cortical dendritic growth. Neuron 18:767-778

McMahon LL, Kauer JA (1997) Hippocampal interneurons are excited via serotonin-gated ion channels. J Neurophysiol 78:2493-2502.

Merlio JP, Ernfors P, Jaber M, Persson H (1992) Molecular cloning of rat trkC and distribution of cells expressing messenger RNAs for members of the trk family in the rat central nervous system. Neuroscience 51:513-532.

Merlio JP, Ernfors P, Kokaia Z, Middlemas DS, Bengzon J, Kokaia M, Smith ML, Siesjo BK, Hunter T, Lindvall O, Personn, H (1993) Increased production of the TrkB protein tyrosine kinase receptor after brain insults. Neuron 10:151-164.

Messaoudi E, Bardsen K, Srebro B, Bramham CR (1998) Acute intrahippocampal inf usion of BDNF induces lasting potentiation of synaptic transmission in the rat dentate gyrus. J Neurophysiol 79:496-499.

Meyer-Franke A, Wilkinson G, Kruttgen A, Hu M, Munro E, Hanson Jr M, Reichardt L, Barres B (1998) Depolarization and cAMP elevation rapidly recruit trkB to the plasma membrane of CNS neurons. Neuron 21:681-693.

Milner TA, Bacon CE (1989) Ultrastructural localization of tyrosine hydroxylase-like immunoreactivity in the rat hippocampal formation. J Comp Neurol 281:479-495.

Morrison ME, Mason CA (1998) Granule neuron regulation of Purkinje cell development: striking a balance between neurotrophin and glutamate signaling. J Neurosci 18:3563-3573.

Mundigl O, De CP (1994) Formation of synaptic vesicles. Curr Opin Cell Biol 6:561-567.

Patterson SL, Grover LM, Schwartzkroin PA, Bothwell M (1992) Neurotrophin expression in rat hippocampal slices: a stimulus paradigm inducing LTP in CA1 evokes increases in BDNF and NT-3 mRNAs. Neuron 9:1081-1088.

Patterson SL, Abel T, Deuel TA, Martin KC, Rose JC, Kandel ER (1996) Recombinant BDNF rescues deficits in basal synaptic transmission and hippocampal LTP in BDNF knockout mice. Neuron 16:1137-1145.

Peters A, Palay SL, Webster HD (1991) The fine structure of the nervous system. New York: Oxford UP.

Pickel VM, Chan J, Aoki C (1993) Electron microscopic immunocytochemical labelling of endogenous and/or transported antigens in rat brain using silver-intensified one-nanometer colloidal gold. In: Immunohistochemistry, Vol II (Cuello A, ed), pp 265-280. New York: Wiley. Pierce JP, Kururz OS, Milner TA (1999) The morphometry of a pepti- 
dergic transmitter system before and after seizure: I. Dynorphin B-like immunoreactivity in the rat hippocampal mossy fiber pathway. Hippocampus, 9:255-276.

Ramon y Cajal S (1911) Histologie du systeme nerveus de l'homme et des vertebres, Vol II. Paris: Maloine.

Reynolds ES (1963) The use of lead citrate at high $\mathrm{pH}$ as an electronopaque stain in electron microscopy. J Cell Biol 17:208-212.

Ribak CE, Seress L, Amaral DG (1985) The development, ultrastructure and synaptic connections of the mossy cells of the dentate gyrus. J Neurocytol 14:835-857.

Rocamora N, Pascual M, Acsady L, de Lecea L, Freund TF, Soriano E (1996) Expression of NGF and NT3 mRNAs in hippocampal interneurons innervated by the GABAergic septohippocampal pathway. J Neurosci 16:3991-4004.

Scharfman HE (1997) Hyperexcitability in combined entorhinal/hippocampal slices of adult rat after exposure to brain-derived neurotrophic factor. J Neurophysiol 78:1082-1095.

Sklair-Tavron L, Nestler EJ (1995) Opposing effects of morphine and the neurotrophins, NT-3, NT-4, and BDNF, on locus coeruleus neurons in vitro. Brain Res 702:117-125.

Soriano E, Frotscher M (1994) Mossy cells of the rat fascia dentata are glutamate-immunoreactive. Hippocampus 4:65-69.

Spenger C, Hyman C, Studer L, Egli M, Evtouchenko L, Jackson C, Dahl-Jorgensen A, Lindsay RM, Seiler RW (1995) Effects of BDNF on dopaminergic, serotonergic, and GABAergic neurons in cultures of human fetal ventral mesencephalon. Exp Neurol 133:50-63.

Stanton PK (1996) LTD, LTP, and the sliding threshold for long-term synaptic plasticity. Hippocampus 6:35-42.

Swanson LW (1995) Brain maps: structure of the rat brain. Amsterdam: Elsevier.

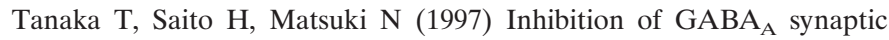
responses by brain-derived neurotrophic factor (BDNF) in rat hippocampus. J Neurosci 17:2959-2966.

Thoenen H (1995) Neurotrophins and neuronal plasticity. Science 270:593-598.

Timmusk T, Belluardo N, Metsis M, Persson H (1993) Widespread and developmentally regulated expression of neurotrophin-4 mRNA in rat brain and peripheral tissues. Eur J Neurosci 5:605-613.
Vazquez ME, Ebendal T (1991) Messenger RNAs for trk and the lowaffinity NGF receptor in rat basal forebrain. NeuroReport 2:593-596.

Venkatesan C, Song X-Z, Go C-G, Kurose H, Aoki C (1996) Cellular and subcellular distribution of alpha2A-adrenergic receptors in the visual cortex of neonatal and adult rats. J Comp Neurol 365:79-95.

Veznedaroglu E, Milner T (1992) Elimination of artifactual labeling of hippocampal mossy fibers seen following preembedding immunogoldsilver technique by pretreatment with zinc chelator. J Microsc Res 23:100-101.

von Bartheld CS, Byers MR, Williams R, Bothwell M (1996a) Anterograde transport of neurotrophins and axodendritic transfer in the developing visual system. Nature 379:830-833.

von Bartheld CS, Williams R, Lefcort F, Clary DO, Reichardt LF, Bothwell M (1996b) Retrograde transport of neurotrophins from the eye to the brain in chick embryos: roles of the p75NTR and trkB receptors. J Neurosci 16:2995-3008.

Wang X, Berninger B, Poo M (1998) Localized synaptic actions of neurotrophin-4. J Neurosci 18:4985-4992.

Wetmore C, Cao YH, Pettersson RF, Olson L (1991) Brain-derived neurotrophic factor: subcellular compartmentalization and interneuronal transfer as visualized with anti-peptide antibodies. Proc Natl Acad Sci USA 88:9843-9847.

Williams M, Hughes P, O’Toole T, Ginsburg M (1994) The inner world of cell adhesion: integrin cytoplasmic domains. Trends Cell Biol 4:109-112.

Wouterlood FG, Saldana E, Witter MP (1990) Projection from the nucleus reuniens thalami to the hippocampal region: light and electron microscopic tracing study in the rat with the anterograde tracer Phaseolus vulgaris-leucoagglutinin. J Comp Neurol 296:179-203.

Yan Q, Radeke MJ, Matheson CR, Talvenheimo J, Welcher AA, Feinstein SC (1997) Immunocytochemical localization of TrkB in the central nervous system of the adult rat. J Comp Neurol [Erratum (1997) 382:546-547] 378:135-157.

Zachrisson O, Falkenberg T, Lindefors N (1996) Neuronal coexistence of trkB and glutamic acid decarboxylase 67 mRNAs in rat hippocampus. Brain Res Mol Brain Res 36:169-173. 